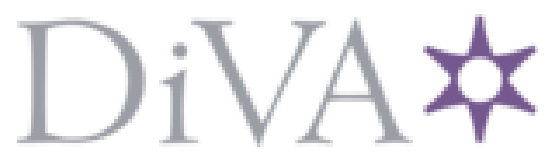

http://www.diva-portal.org

\title{
Postprint
}

This is the accepted version of a paper published in Cold War History. This paper has been peerreviewed but does not include the final publisher proof-corrections or journal pagination.

Citation for the original published paper (version of record):

Scott, C-G. (2009)

Swedish Vietnam criticism reconsidered: Social democratic Vietnam policy a manifestation of Swedish Ostpolitik?.

Cold War History, 9(2): 243-266

http://dx.doi.org/10.1080/14682740802490273

Access to the published version may require subscription.

N.B. When citing this work, cite the original published paper.

Permanent link to this version:

http://urn.kb.se/resolve?urn=urn:nbn:se:esh:diva-4673 
Carl-Gustaf Scott

\section{Swedish Vietnam Criticism Reconsidered: Social Democratic Vietnam Policy a Manifestation of Swedish Ostpolitik? \\ Introduction}

By the mid-1960's, like other West European states, Sweden had embraced the détente for a combination of economic, political, and geo-strategic reasons. Sweden further followed the French - - and to an even greater extent the German - - lead in trying to normalize relations with the Soviet Union and the rest of the Eastern bloc. ${ }^{i}$ Because the country's rapprochement with the USSR overlapped with stepped up Swedish protests against the American war effort in South East Asia, this article examines what role, if any, Social Democratic Vietnam policy played in the outward expression of Swedish Ostpolitik.

Between 1965 and 1973, Sweden's Social Democratic government, led by Olof Palme, emerged as the most strident and persistent non-Communist critic of the Vietnam War. ${ }^{\text {ii }}$ Indeed, from the Americans' point of view, it did not take long before Palme supplanted Charles de Gaulle as the most recognizable European opponent of U.S. policy in South East Asia. ${ }^{\text {iii }}$ In addition to its verbal attacks against the war, the Social Democratic administration granted sanctuary to American deserters while concomitantly providing economic and political support to Hanoi. The Swedish-American conflict over Indochina finally climaxed in January 1973 when President Richard Nixon froze diplomatic relations with Sweden in response to Palme's comparison between the Holocaust and the 1972 American Christmas bombings of North Vietnam. ${ }^{\text {iv }}$

Although the Social Democratic administration was genuinely opposed to the war, its militancy on the Vietnam question can nevertheless only be understood in the 
context of the party's efforts to prevent its domestic Communist rivals from capitalizing on widespread public antipathy toward the war. ${ }^{\mathrm{v}}$ In particular, the leadership of the SAP (Sveriges Socialdemokratiska Arbetareparti) worried that the young might forsake the party for other, more radical, political alternatives. ${ }^{\text {vi }}$ Accordingly, it was absolutely imperative that the government take a strong public stance on the Vietnamese conflict. ${ }^{\text {vii }}$

Beyond its immediate domestic origins, this policy soon also had major implications for the country's foreign relations. Social Democratic Vietnam criticism, notably, did much to raise Sweden's international visibility. This policy further won the Social Democrats many new friends in the Developing World ${ }^{\mathrm{viii}}$ - - and it was, in fact, intended to achieve this exact result. ${ }^{\text {ix }}$ (In this regard, Swedish Vietnam policy was very reminiscent of its French counterpart, which was likewise designed to curry favor in the Third World.) ${ }^{\mathrm{x}}$ More importantly, Sweden's outspoken approach to the war had significant consequences for its relations to both superpowers.

While a large number of studies have already looked at how this policy strained the county's historically amicable relationship with the U.S., ${ }^{\text {xi }}$ very little has been written about its effect on Sweden's rapport with the USSR. ${ }^{\text {xii }}$ Utilizing recently released U.S. and Swedish government documents, this article discusses how Social Democratic Vietnam policy specifically impacted Swedish-Soviet relations (which up until this point in the Cold War had not been very warm.) It concludes that - - regardless of whether or not this policy was, at first, intentionally designed to have this effect - - it ultimately served to put the two countries' relationship on a better footing.

The available evidence, in contrast, tells us less about the intent behind this policy in relation to the USSR. Was Social Democratic Vietnam criticism consciously 
calculated to win the Kremlin's good-will, or was Soviet approval simply an unintentional bi-product of it?

The answer can at least partially be found in Swedish threat perceptions - - though this matter in itself is not so easily resolved. In part this ambiguity stems from the fact that Social Democratic leaders in this era seldom discussed publicly Swedish foreign policy in strictly geo-strategic terms; and in part, it is because the party was internally divided about to what extent the USSR was still a military threat to Sweden. By the late 1960's - early 1970's, the SAP's left-wing insisted that the détente had done much to reduce this danger. Yet, threat perceptions do not always accurately reflect geo-strategic realities, and this optimistic assessment was certainly not shared by everyone on the party's right. ${ }^{\text {xiii }}$ That said, once the party had officially tied itself to the détente's success, it would have been an electoral liability to express any privately held misgivings about the Soviet Union's growing power, both in Europe, and globally. Consequently, Social Democratic leaders had seemingly little incentive to be forthright about this subject.

Consequently, it is very difficult, in retrospect, to establish what the inner circle of the SAP hierarchy truly thought about this issue. Still, one can draw some tentative conclusions from Sweden's international conduct in this period, which was often noticeably deferential toward the Soviet Union. At the time, such behavior was by no means unique to Sweden, as all Western European states' relations with the USSR were implicitly informed by the relative decline of American economic and military strength as well as by the Soviets' attainment of (near) nuclear parity. Given that Swedish Vietnam criticism coincided with these two developments, this article asks whether this policy might be interpreted as one component in a broader strategy to secure the Kremlin's good 
graces at a time when the strategic balance in Europe appeared to be on the verge of shifting in the USSR's favor?

\section{Social Democratic Vietnam policy a Manifestation of Swedish Ostpolitik?}

Officially, Sweden was neutral in the Cold War, though its non-aligned status did not prevent it from openly linking itself to the West - - culturally, politically, and economically. Sweden, moreover, largely shared the same security concerns as its West European NATO neighbors, and therefore Swedish energies were generally directed at safeguarding the postwar status quo. In comparison to the Social Democratic administration's militancy on the Vietnam question, it adopted a considerably more subdued approach to European affairs. This disparity was best illustrated by Sweden's decision to become the first Western country to diplomatically recognize North Vietnam, while at the same time refusing to extend such recognition to East Germany. ${ }^{\text {xiv }}$ The SAP leadership likewise conspicuously dissociated itself from Gaullism (refusing to back the French challenge against the dollar, etc.) Overall, the Swedes pursued a fundamentally pro-American policy in Europe that was underscored by their insistence that the U.S. be included into the Conference on Security and Co-operation in Europe (CSCE). ${ }^{\mathrm{xv}}$ The radical positions that frequently characterized Social Democratic policy toward the Third World were thus largely absent in Sweden's dealings with Europe. ${ }^{\text {xvi }}$ Closer to home, Realpolitik concerns were the order of the day, with special attention being paid to strategic changes in the northern Europe. ${ }^{\text {xvii }}$

The basic fact of Swedish foreign policy is the nation's geographic location, ${ }^{\text {xviii }}$ which was not affected by the Social Democratic administration's increasingly vocal international profile. As a result Sweden's proximity to Russia would always be at the 
center of the government's foreign policy formulation, and this was as true in the 1960's and 1970's as it had been Tsarist times. Historically Russia had been the Swedes' principle antagonist, and the outcome of the Second World War had merely confirmed that the USSR would continue to be the primary threat to Swedish security. In view of the country's location and small-power status, it was vital for Stockholm to foster cordial, if not amiable, relations with Moscow. ${ }^{\text {xix }}$

Throughout the entire Cold War, caution served as the leitmotiv of Swedish policy vis-à-vis the Soviet Union. China's emergence as a Great Power in the 1960's was of little direct consequence to Swedes, and so, like other Western Europeans, they were not overly concerned about the prospect of Chinese expansionism in Asia. ${ }^{\mathrm{xx}}$ Lacking global responsibilities, Sweden's security concerns remained centered in northern Europe, and any alterations in balance of power in the Baltic were therefore carefully scrutinized. Modern Swedish diplomacy largely had been shaped by the need to accommodate these shifts, and the country's policy of neutrality had consistently been formulated in accordance with this proscription. ${ }^{\mathrm{xxi}}$ In the Vietnam era, this meant that the Swedes would exhibit extra sensitivity to the Soviet viewpoint. ${ }^{\text {xii }}$

From the mid-1960's on, Sweden's strategic position in relation to the Soviet Union progressively eroded, and from a purely military standpoint the Soviet peril was actually intensifying, this in spite of the détente. On a regional level, the USSR's armed might in northern Europe was considerably strengthened in light of its escalating military build up on the Kola Peninsula. The latter phenomena was a by-product of the vast expansion of the Soviet navy that had gotten underway in the early 1960's, which soon made itself felt in both the Baltic and in the north Atlantic. These developments acted to 
tilt the balance of power in Scandinavia even further in Moscow's favor - - where it already previously had enjoyed a substantial military advantage. The Soviets' concomitant achievement of near nuclear parity in the later half of the 1960's only served to reinforce the USSR's dominance in northern Europe, as it greatly inflated the strategic importance of the Warsaw Pact's conventional forces. (The latter were no longer offset by NATO's earlier nuclear superiority.) ${ }^{\text {xxiii }}$ Located at the western doorstep of the Soviet sphere, Sweden could not realistically afford to ignore the USSR's rising military strength, either globally or regionally. ${ }^{\text {xiv }}$

The heightened projection of Soviet military power in the northern Europe was noted with great alarm by the Swedish Armed Forces. ${ }^{\mathrm{xxv}}$ Although Swedish military planners conceded that the détente had reduced the risk of war in Europe (and by extension also of an attack against Sweden), they insisted that the country still had to be vigilant about the Soviet threat. ${ }^{\text {xxvi }}$ In their eyes, the USSR remained a serious danger to the nation's security, and for this reason the Armed Forces' strategic outlook did not undergo any significant revision during the Vietnam era. ${ }^{\text {xxvii }}$

Unlike the military, the Social Democratic establishment - - at least outwardly - assumed a far more optimistic view of the détente's sustainability. ${ }^{\text {xxviii }}$ While the SAP hierarchy was by no means unaware of the Soviets' growing military capacity, ${ }^{\mathrm{xxix}}$ it nonetheless proposed that the recent relaxation in East-West tensions justified significant cuts in military expenditures, which soon also occurred. The Command of the Armed Forces naturally disagreed with this assessment, feeling that the country's defense posture was recklessly being subordinated to political dictates that had little bearing on Sweden's present strategic situation. ${ }^{\mathrm{xxx}}$ 
This evaluation was seconded by American officials, who privately thought that the Social Democratic administration was overly anxious to embrace the détente, to the point of willfully ignoring the lingering Soviet threat to Europe. From the former's point of view, the SAP leadership appeared to be recklessly gambling on the détente in hopes of slashing defense spending. ${ }^{\text {xxi }}$ Cuts in the Swedish defense budget immediately raised concerns among American observers, who judged that the quality Sweden's military was rapidly deteriorating as a result. ${ }^{\text {xxxii }}$ In these years, this problem caused considerable headaches for Washington in its dealings with Western Europe as a whole, since almost all of its allies had used the détente as a license to disarm. This issue, however, was not easily addressed in light of the Americans' own intensified pursuit of better relations with the Soviet Union, which made it very difficult for the U.S. to persuade its allies to continue to maintain high levels of defense expenditures. ${ }^{\text {xxiii }}$ Sweden's conduct in this instance hence fit into a much broader West European pattern of behavior.

Positioned on the front line of the Cold War, the Swedes obviously had solid security reasons to support the détente, and it is no coincidence that Finland and Austria were two of the other most energetic West European promoters of the détente. ${ }^{\text {xxiv }}$ Such geo-strategic logic was, then, augmented by its political advantages, as the relaxation of East-West tensions provided Sweden, ${ }^{\mathrm{xxxv}}$ along with the rest of Western Europe, with greater autonomy vis-à-vis the superpowers. ${ }^{\text {xxvi }}$ (Sweden's rhetorical challenge of American policy in South East Asia would, in fact, have been inconceivable in a frostier Cold War climate.) $)^{\mathrm{xxxvii}}$

Viewed from this perspective, the Social Democrats' wholehearted promotion of the détente is quite understandable. ${ }^{\text {xxxvii }}$ While the latter did not fail to appreciate the 
inherent danger of a rapprochement between Washington and Moscow (which carried the risk of superpower collusion at Europe's expense), ${ }^{\mathrm{xxxix}}$ SAP leaders seem to have felt that the détente's benefits outweighed its potential hazards. From the very start, the party hierarchy's opposition to the American war effort had in large part been rooted in a concern that the Vietnamese conflict might jeopardize the emerging thaw in Europe. ${ }^{\mathrm{xl}}$

To be sure, the SAP leadership's endorsement of the détente also had a strong domestic dimension to it (which did not escape the attention of American officials.) ${ }^{\mathrm{xli}}$ At a time when the Swedish economy was finally starting to cool off after nearly two decades of unprecedented growth, the Social Democratic administration sought to divert funds away from the Armed Forces in order to defray the costs of escalating social expenditures. The health of the welfare state was key to the SAP's continued political success, and in the 1960's the party leadership came under considerable domestic pressure to curb military spending - - due to a mixture of pacifistic and welfare-related motives. ${ }^{\text {xlii }}$ In the end, internal left-wing agitation won out, resulting in a significantly weakened Swedish defense. ${ }^{\text {xliii }}$

Once the cabinet had committed itself fully to the détente, and began to substantially scale back on the country's military capacity, this by default necessitated deepened rapprochement with the Soviet Union. ${ }^{\text {xliv }}$ Conversely, a more conciliatory line toward the USSR was perhaps partially chosen for the very reason that it allowed the government to prioritize social expenditures over soaring defense-related costs. ${ }^{\mathrm{xlv}}$ Either way, diplomacy was now in effect given total precedence as Sweden's first line of defense against Soviet encroachment. ${ }^{\text {xlvi }}$ (During these years, an identical trend was, for instance, evident in Austrian foreign policy as well. $)^{\mathrm{xlvii}}$ 
This reorientation of Swedish security policy was buttressed by the relative decline of U.S. power that was concurrently taking place, which in no small measure was a product of America's deepening involvement in Indochina. The Swedes were very cognizant of the economic and political toll that the Vietnamese conflict was having on the United States, ${ }^{\text {xlviii }}$ not least on American public opinion. Swedish diplomats in Washington kept a watchful eye on the resurgence of neo-isolationist sentiments. ${ }^{\text {xlix }}$

Back in Sweden, members of the non-socialist opposition were more apt than their Social Democratic counterparts to express apprehension about the paralyzing effect that neo-isolationist attitudes might have on U.S. foreign policy, ${ }^{1}$ though occasionally this problem was also touched upon by Social Democratic spokesmen. ${ }^{\text {li }}$ SAP leaders were comparatively more forthcoming about their worries relating to the war's detrimental impact on America's international prestige, specially in Western Europe. ${ }^{\text {lii }}$ Over the course of the 1960's, the Swedes had anxiously watched from the sidelines how various disagreements (including ones about the Vietnamese conflict) had upset the internal cohesion of the Western alliance. liii $^{\text {in }}$

The war's negative psychological effect on U.S.-West European relations should not be underestimated. The West Germans' profound disillusionment with the American war effort, for example, served as a catalyst for a less-deferential attitude toward Washington and for a more independent international posture.$^{\text {liv }}$ One can reasonably infer that the same was true for Sweden given that the war did not garner much confidence in America's global leadership anywhere in Western Europe. ${ }^{\mathrm{lv}}$

In Sweden (like elsewhere in the West) there was also substantial concern that the Vietnamese conflict was dangerously overextending the U.S.'s military and economic 
resources. ${ }^{\text {lvi }}$ Not unexpectedly, diplomatic reports closely monitored American troop withdrawals from the Continent, ${ }^{\text {lvii }}$ and the overall deterioration of the U.S.'s military standing in Europe was of course followed intently by Swedish politicians and diplomats alike. ${ }^{\text {lviii }}$ There was a general feeling that the Americans had shifted their attention to Asia and that they had started to dissociate from Europe. ${ }^{\text {lix }}$ Admittedly, the signals emanating from Washington were somewhat mixed, and because of this, its future intentions with regard to Europe remained ambiguous. What was more clear-cut was that the U.S. - - in the name of fiscal re-entrenchment - - intended to drastically reduce its overseas commitments. $^{\mathrm{lx}}$

Considering that Swedish security implicitly relied upon American protection, any weakening of either NATO or the U.S.'s commitment to Europe was bound to be unwelcome news in Stockholm. Non-socialist politicians were often rather candid about this point, ${ }^{\text {lxi }}$ whereas Social Democratic officials were less prone to discuss this issue publicly. ${ }^{\text {lxii }}$ (In private, however, the latter were more willing to acknowledge that the country's security was ultimately dependent upon a continued American military presence in Europe. $)^{\text {lxiii }}$ Now that this basic assumption that Swedish national security rested upon was suddenly in question, Stockholm had powerful incentive to reorient its security policy in a more Moscow-friendly direction.

While the origins of West German Ostpolitik were multifaceted and are too numerous and complex to discuss in detail here, ${ }^{\text {lxiv }}$ this policy was partially founded on the notion that Germany needed to reach an understanding with the Kremlin in the event that the U.S. disengaged from Europe. Confronted with this prospective scenario, the Federal Republic braced itself for having to face the Soviets alone, and, accordingly, 
Bonn set out to forge an independent relationship to Moscow. West Germany was not switching sides or sympathies in the Cold War; instead, this adjustment was solely brought about by a new set of geo-strategic realities. ${ }^{\text {lxv }}$ Once again it should be underlined that in the late 1960's many West Europeans feared that the global balance of power might tilt decisively toward the Soviets. ${ }^{\text {lxvi }}$

Swedish Ostpolitik was seemingly based on a like-minded premise, as is indicated by Palme's remarks to the Social Democratic parliamentary group that: "if difficult situations were to occur in the future, it is important that there already exists personal contacts [between Swedish and Soviet leaders] and that the USSR has knowledge about how we in Sweden think and react." "lxvii These comments strongly suggest, that similar to Bonn, Stockholm recognized the strategic (or at least the political) necessity of cultivating a stronger rapport with the Soviet Union.

Yet this does not mean, as some have asserted, ${ }^{\text {lxviii }}$ that Sweden had turned its back on the West. Nor is there any reason to believe that Social Democratic support for the Vietnamese Communists reflected a newfound preference for the Soviet system. Like West Germany, Sweden's desire to improve its relationship with the USSR was largely dictated by geo-strategic calculations.

This argument is partially predicated on the knowledge that the Swedish Social Democrats were very familiar with the genesis of German Ostpolitik. Stockholm had actually played a pivotal role in initiating Bonn's opening to the East, ${ }^{\text {lxix }}$ and had been a tireless advocate of German Ostpolitik thereafter. ${ }^{\text {Ixx }}$ In virtue of the Swedish Social Democrats' close personal contacts with the leadership of the German Social Democratic Party (Sozialdemokratische Partei Deutschlands, SPD), they had exceptional insight into 
the aims, trajectory, and driving motives behind Bonn's Ostpolitik. ${ }^{\text {lxxi }}$ Given that all Scandinavian Social Democratic parties were greatly influenced by their German colleagues' thinking about this topic, ${ }^{\text {xxii }}$ one can safely assume that the SAP hierarchy grasped the geo-strategic implications of the SPD's Eastern policy, particularly since Sweden's own security concerns in some ways mirrored those of the F.R.G.'s.

As elsewhere in Western Europe, ${ }^{\text {lxiii }}$ the country's Ostpolitik was furthermore driven by the wish to increase trade with the Eastern bloc, and some modest gains were achieved in this area. ${ }^{\text {lxxiv }}$ (Swedish industrialists had naturally also greeted the possibility of expanded markets in the East. $)^{\operatorname{lxxv}}$

That Stockholm's attempt to nurture closer relations with Moscow was to a certain degree economically motivated was instantly transparent to foreign observers; ${ }^{\text {lxxvi }}$ though most international commentators still tended to view Sweden's opening to the East principally in strategic terms, motivated by the aforementioned changing balance of power in Europe. ${ }^{\text {lxxvii }}$ The Swedes' burgeoning cordiality vis-à-vis the USSR was thus widely recognized at the time, including on Capitol Hill. ${ }^{\text {lxxviii }}$

Needless to say, this general development was also registered by U.S. officials in Stockholm, who did not fail to comprehend the geo-strategic subtext of the Social Democratic administration's rapprochement with the Soviet Union. ${ }^{\text {lxix }}$ Indeed, for the Americans, Stockholm's intensified efforts to reach out to Moscow were unmistakable. $^{\text {lxxx }}$ This conclusion was in part based on the sharp rise in diplomatic contacts between Sweden and the Warsaw Pact states ${ }^{1 \mathrm{xxxi}}$ - - a trend that had become more and more discernable from the mid-1960's on. ${ }^{\text {lxxii }}$ (Such exchanges were later further supplemented by a number of courtesy military visits). ${ }^{\text {lxxiii }}$ 
This supposition, moreover, derived from the Social Democratic administration's increasingly cautious posture vis-à-vis the Soviet Union, ${ }^{\text {lxxiv }}$ which has also been duly noted by various domestic critics (both at time and in hindsight). ${ }^{\operatorname{xxxv}}$ Since the end of the Cold War, some have interpreted the Social Democratic administration's "appeasement" of the Soviet Union as a form of overcompensation for the country's covert military ties to the West (a point to which I will return). ${ }^{\text {lxxvi }}$ This be as it may - - at a minimum - Sweden's great sensitivity toward the USSR in this period is irrefutable. ${ }^{\text {lxxxvii }}$

Students of this topic have often pointed to the Social Democratic administration's withdrawal of the country's EEC application in 1970 as evidence of its new "Soviet-friendly" attitude. ${ }^{\text {lxxxviii }}$ Although it was no secret that the Kremlin was adamantly opposed to Swedish EEC membership, ${ }^{\text {lxxix }}$ the cabinet also had very compelling domestic reasons for dropping the application. ${ }^{\mathrm{xc}}$ This might be a misleading example, then, since the actual significance of the Soviet veto is not really definite.

This anxiousness to place relations with Moscow on a more solid footing was more straightforwardly demonstrated by the government's reoccurring expressions of Swedish-Soviet friendship. ${ }^{\text {xci }}$ This tendency was further highlighted by the fact that Sweden's earlier criticism of the Soviet Union largely vanished during the Vietnam era, while its attacks against the U.S., on the other hand, concomitantly skyrocketed. ${ }^{\text {xii }}$ Not only did Social Democratic spokesmen begin to criticize America much more frequently than they did the USSR, but the U.S. was also condemned in much stronger language. ${ }^{\text {xciii }}$ It goes without saying that the Americans never constituted any direct strategic threat to Sweden, and therefore the Social Democratic critique of the Vietnam War was a relatively low-risk policy - - one that was worth pursuing in view of its potential domestic 
dividends. For in these years, standing up to Washington was often good politics in Western Europe. In this sense, the Swedish challenge to the U.S. was in many ways analogous to its French counterpart, as they were both fundamentally symbolic in nature. ${ }^{\text {xciv }}$ In contrast, it would have been far too dangerous to pursue comparable policy toward the USSR.

In the late 1960's and early 1970's, this disparity was repeatedly remarked upon by both American diplomats ${ }^{\mathrm{xcv}}$ and the Social Democrats' domestic critics. ${ }^{\mathrm{xcvi}}$ (This subject has remained a major source of contention in Sweden.) ${ }^{\mathrm{xcvii}}$ The former SAP Party Secretary Sten Andersson recently confirmed that the government's tone toward the U.S. was typically much harsher than the one it used with the Soviet Union in this period. Andersson explained that this difference was due to a combination of political and geostrategic factors, which taken together demanded a more-guarded comportment vis-à-vis the USSR. ${ }^{\text {xcviii }}$ According to the government's detractors, this distinction was extremely perceptible in the Social Democrats' approach to the situation in Indochina, as the SAP hierarchy habitually seemed to overlook the Chinese and Soviet role in the war. ${ }^{\text {xcix }}$

In fact, at the time, many regarded the Social Democratic administration's onesidedness in the Vietnamese conflict as a calculated policy of accommodation toward the

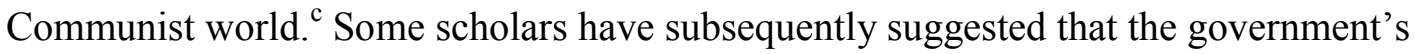
endorsement of the Vietnamese Communists, and other revolutionary movements in the Third World, was deliberately intended to secure Soviet good-will ${ }^{\text {ci }}$ (though no one has yet interpreted this as a key manifestation of Swedish Ostpolitik.) During the war, this opinion was fairly widespread, both domestically ${ }^{\mathrm{cii}}$ and internationally ${ }^{\mathrm{cii}}$ - - and it was definitely the prevailing view among American officials. ${ }^{\text {civ }}$ Like-minded sentiments were 
also vocalized by conservatives on Capitol Hill, who routinely construed Social Democratic support for the Democratic Republic of Vietnam/National Liberation Front as evidence of Stockholm's eagerness to run Moscow's errands. ${ }^{\mathrm{cv}}$

Social Democratic leaders have not surprisingly denied that the government's strident opposition to the war was meant to court the Kremlin's favor, and they have additionally rejected the proposition that it indirectly served Soviet propaganda purposes. ${ }^{\text {cvi }}$ Apologists of the government's Vietnam policy have usually cited Sweden's vocal objection to the Soviet invasion of Czechoslovakia in August 1968 as proof that the Social Democratic administration was not pursuing a policy of accommodation toward the USSR. ${ }^{\text {cvii }}$ In the immediate wake of the Red Army's crushing of the Prague Spring this same argument was repeatedly made by Palme himself, who sought to establish the SAP leadership's lack of anti-American bias by equating Swedish Vietnam criticism to its protest against the Soviet invasion. The subtext of this comparison was to show that the Social Democratic administration was following a completely independent course in world affairs that was equally critical of both superpowers. ${ }^{\text {cviii }}$

It is correct to state that the Swedish condemnation of the Soviet invasion was relatively harsh by international standards, ${ }^{\text {cix }}$ yet it must be stressed that this criticism was distinguishable exactly because it was the exception to the rule. Otherwise, Swedish rebukes of the Soviet Union were rarely heard in this era. ${ }^{\mathrm{cx}}$ More significantly, this particular episode did not have any long-term detrimental impact on Sweden's rapprochement with the USSR. ${ }^{\text {cxi }}$ Unlike Social Democratic Vietnam criticism, which aggravated Swedish-American diplomatic relations for nearly a decade, Moscow's irritation with Stockholm was short-lived. ${ }^{\text {cxii }}$ Undoubtedly, this mostly reflected the 
reality that this was an isolated incident, though it was probably also because the Swedish protest was lost in the broader chorus of international outrage about the invasion. ${ }^{\text {cxii }}$ Another possible reason why the government's denunciation did not end up having any far-reaching consequences for Swedish-Soviet relations, was almost certainly because the Kremlin recognized the domestic calculations motivating the Social Democrats' conduct. ${ }^{\text {cxiv }}$ In this case, the SAP's criticism of the USSR occurred within the specific confines of the final weeks of the 1968 election campaign. It appears that the Social Democrats first and foremost employed this incident to profile their antiCommunist credentials to moderate swing voters, ${ }^{\mathrm{cxv}}$ though they likewise seized upon the suppression of the Prague Spring as an excellent opportunity to discredit the Swedish Communist Party. Traditionally, the SAP's most strident attacks against the Soviet Union had been reserved for occasions when it sought to tarnish the credibility of its domestic Communist rivals, and the party's behavior in conjunction with the Czechoslovakian invasion was consistent with this norm. ${ }^{\text {cxvi }}$ Consequently, there is good reason to believe that the Kremlin was well aware of the electoral motives behind the Social Democrats' anti-Soviet protest in August 1968. ${ }^{\text {cxvii }}$ (Nor was the USSR, for that matter, blind to the party tactical dimension driving Swedish Vietnam policy.) ${ }^{\text {cxviii }}$ As for the Czechoslovakian situation, Moscow does not seem to have been very upset with Stockholm. This conclusion can be deduced from the fact that the Soviet press avoided any direct criticism of the Social Democrats until the election was over, which, in turn, suggests that the Kremlin wanted the SAP to remain in power. ${ }^{\text {cxix }}$

Heading into the 1970 election, the USSR's preference for continued Social Democratic rule was made even more explicit by the royal treatment that was bestowed 
upon Olof Palme during his June visit to Moscow. Apparently, the Soviets hoped that their warm reception of the Swedish Prime Minister would bolster the SAP's electoral prospects in the upcoming September election. ${ }^{\text {cxx }}$ Beginning around 1967, the Soviet media started to portray the Swedish Social Democrats in an increasingly positive light, thereby signaling the Kremlin's approval. To Moscow, a Social Democratic government was always more desirable than a non-socialist one, as the latter was likely to steer Swedish foreign policy in a more overtly pro-Western direction. ${ }^{\text {cxxi }}$

The Swedish-Soviet rapprochement had gotten off to a halting start in the mid1960's ${ }^{\text {cxxii }}$ - - and despite being briefly interrupted by the Czechoslovakian episode - - it is fair to say that by the mid-1970's the two countries' relationship had never been better (at least not in recent memory). ${ }^{\text {cxiii }}$ In these years, both sides testified to the everimproving state of their mutual interactions and they continually affirmed that the two nations had no real bilateral problems to speak of. ${ }^{\text {cxxiv }}$ This new amicable chapter in Swedish-Soviet relations survived for over a decade, peaking the late 1970's, before eventually being undercut by suspected Soviet submarine intrusions in the early 1980's. ${ }^{\text {cxxv }}$ (Even well after this, the Swedish Social Democrats' international nuclear initiatives found a very receptive audience in the USSR.) ${ }^{\text {cxxvi }}$

Soviet enthusiasm for Swedish foreign policy grew progressively in the Vietnam era, during which time Moscow dropped its earlier opposition to Swedish neutrality, and instead began to praise it publicly. Yet such benevolent expressions did not mean that the USSR intended to respect Sweden's neutrality in the case of war - - nor did it signify that the Kremlin had acquired any more faith in Stockholm's declared intent to remain neutral in the event of renewed hostilities in Europe. (In reality, the Soviets never had much 
confidence in Sweden's policy of non-alignment, largely because they were well informed about the country's clandestine military ties to the Western alliance.) What it did mean, however, was that the USSR had started to value the political utility of Swedish neutrality. ${ }^{\text {cxxvii }}$ Very early on in the Cold War, the Kremlin had realized that the Swedes felt obliged to make certain political gestures toward the Soviet Union in order to compensate for their otherwise pro-Western orientation, and it naturally sought to exploit this tendency. ${ }^{\text {cxxviii }}$ In the late 1960's and early 1970's, Stockholm's rising stock in Soviet eyes was above all attributable to the Social Democrats' new international profile, including the latter's outspoken opposition to the American war effort in South East Asia. ${ }^{\text {cxxix }}$ And even though the last mentioned policy only represented a small part in the totality of Sweden's dealings with the USSR during this period - - it proved to be a critical one.

In light of newly declassified Swedish government documents, previous scholarship on this topic has probably underestimated the degree to which the Kremlin approved of the Social Democrats' Vietnam policy. ${ }^{\text {cxxx }}$ The hypothesis that Moscow was not overly keen about the SAP's anti-war stance derives from the observation that the Soviets did not make as much of the Swedish position as one might have expected them to do. ${ }^{\text {cxxxi }}$ While it might be true that the Soviets did not fully capitalize on Swedish opposition to the war, they still made ample use of it. The Social Democrats' militancy on Indochina received a lot of favorable press, not just in the Soviet Union but everywhere in the Eastern bloc. ${ }^{\text {cxxxii }}$ The Social Democratic administration's decision to recognize the Democratic Republic of Vietnam, in particular, was hailed in the 
Communist media, which was to be expected since Sweden was the first Western country to do so. ${ }^{\text {cxxxiii }}$

By virtue of the country's neutral status, Sweden's attacks on U.S. policy were unquestionably of significant propaganda value to the USSR, especially at a time when its own Vietnam posture was fairly restrained in order to not jeopardize relations with Washington. ${ }^{\text {cxxxiv }}$ (In all likelihood this is the real reason why the Soviets did not try to make more out of the Social Democrats' anti-war protests.) ${ }^{\text {cxxxv }}$ From the Kremlin's point of view, the potential import of Sweden's contribution to the general dissemination of anti-American sentiments in Europe can hardly be overstated; the Soviets' repeated pleas for the Social Democratic administration to assume an even greater role in creating international opinion against the war testifies to this fact. ${ }^{\text {cxxxvi }}$ Presumably, Moscow hoped that Swedish Vietnam criticism would resonate particularly in Oslo and Copenhagen. It must be recalled that the Soviets' overarching objective toward Norway and Denmark throughout the Cold War was to try to draw them both into neutralism, ${ }^{\text {cxxxii }}$ and to the extent that Sweden fanned anti-NATO opinion among its Nordic neighbors this was surely welcomed by the Kremlin.

That the SAP's Vietnam stance played into Soviet hands - - albeit perhaps unwittingly - - did not escape contemporary observers. ${ }^{\text {cxxxviii }}$ The Swedish non-socialist press frequently commented upon the warm reception that the Social Democratic administration's Vietnam policy regularly received in the USSR. ${ }^{\text {cxxix }}$ By and large U.S. officials were of the same opinion, feeling that Sweden was vulnerable to Soviet propaganda in relation to this question, and for this reason they more than once cautioned 
Swedish officials that Moscow would be quick to employ Social Democrats' opposition to the war for its own ends. ${ }^{\mathrm{cxl}}$

The USSR's utilization of Sweden to advance its own agenda was aptly illustrated by the Kremlin's handling of the deserter issue. The Soviet Union was of course happy to see American GI's defect but was not interested in granting them asylum, and all of the U.S. soldiers who at first had escaped to the USSR were later passed on to Sweden. Once the deserters had outlived their political purpose, Moscow did not seem to want to keep them around, and Stockholm helped to resolve this problem by providing a permanent refuge for the deserters. Although the Social Democratic administration did so for its own party tactical reasons, ${ }^{\text {cxli }}$ this practice de facto served Soviet aims, seeing as the American defectors were allowed to engage openly in anti-war propaganda while on Swedish soil.

All in all, then, the Soviets had plenty of reasons to be pleased with Swedish Vietnam policy. Such approval was conveyed both via the Soviet media and more directly in numerous official pronouncements. ${ }^{\text {cxlii }}$ This appreciation was additionally confirmed in private discussions between Swedish and Soviet diplomats. Behind closed doors the latter repeatedly hailed the Social Democrats' Vietnam position, praising Sweden's crucial contribution to building international opposition to the war. $^{\text {cxliii }}$

In truth, Moscow's real opinion of Swedish Vietnam policy will not be known until primary research has been conducted in the Soviet archives. Still, what the Social Democratic leadership at the time believed that the Soviets thought is more important than what the latter really thought. In other words, even if one was able to establish that the SAP's Vietnam posture did not overly impress the USSR, this does not mean that it 
was not intended to do so. In the later half of the 1960's, SAP spokesmen more than once acknowledged that the government's Vietnam policy was popular in Moscow, ${ }^{\text {cxliv }}$ and this impression still survives among former Social Democratic officials. ${ }^{\text {cxlv }}$ With this in mind, it is highly probable that the SAP hierarchy at a very early stage recognized that the party's anti-war profile could also be employed to obtain Soviet good-will, thereby surpassing this policy's primary, and more narrow initial, domestic function. Looking back, it is hard to believe that this dimension of the government's Vietnam policy did not eventually factor actively into the SAP leadership's approach to the war- - if only as a secondary consideration.

What is more certain is that this policy served to facilitate better relations between Stockholm and Moscow. Sweden's rapprochement with the USSR would have occurred even without the Vietnam issue, but this subject acted as a crucial bridge between the Swedes and the Eastern bloc. Starting from 1965 on, the Vietnamese conflict prominently figured in all of Sweden's official interactions with the Warsaw Pact states $^{\text {cxlvi }}$ in a way that it did not in the country's dealings with other Western nations. In this era state visits between Sweden and various individual Eastern bloc countries invariably concluded with a joint communiqué underlining their similar views about the situation in Indochina. ${ }^{\text {cxlvii }}$ The mutual emphasis on this question, most likely stemmed from the reality that Sweden and the Warsaw Pact states did not really have much else in common with each other, that is, beyond their shared antipathy toward the U.S. war effort. Social Democratic leaders were quite frank about this, ${ }^{\text {cxlviii }}$ and this point of Soviet-Swedish agreement was also noted by American officials. ${ }^{\text {cxlix }}$ All told, it is clear 
that Social Democratic Vietnam policy came to function as a critical component of Swedish Ostpolitik, as it opened the door to an improved dialogue with the East.

No less importantly - - whether the product of a calculated policy or not - - the Social Democrats' Vietnam stance likewise proved to be an ingenious way of wooing the Kremlin without alienating domestic opinion, as the Swedish public remained cool toward the Soviets. ${ }^{\mathrm{cl}}$ Such antipathy was especially evident among younger radicals who were as antagonistic toward the USSR as they were ambivalent about the U.S. ${ }^{\text {cli }}$ If the Social Democrats hoped to win the loyalty of this segment of the population any overt courtship of the Soviet Union was out of the question. Hence, the benefit of this approach was not limited to its geo-strategic virtues, as it was of equal merit for domestic reasons.

The primary strength of this policy, however, was that it was nominally acceptable to the Americans in a way that Swedish accommodation toward the USSR in European affairs never would have been. While American policy-makers were indisputably irritated by the Social Democratic administration's anti-war position, they never questioned the Swedes' allegiance to the West. ${ }^{\text {clii }}$

Here it should be emphasized that Sweden's security was virtually as dependent on U.S. protection as was any of the formal members of the Western alliance. Recent research has revealed that - - the country's officially declared policy of neutrality notwithstanding - - Sweden had been clandestinely included into NATO's defensive perimeter in northern Europe in early 1950's, and a decade later it also had been brought under the American nuclear umbrella. The Swedes were likewise integrated into the West's intelligence network against the East. Both sides were eager to keep this area 
separate from their disagreement about the war, and Swedish-American collaboration in the military realm actually intensified during the Vietnam era. ${ }^{\text {clii }}$

In the long run, differences over Indochina did not change the reality that the two countries' security interests in northern Europe, though not identical, in many respects overlapped. The Vietnam issue was basically irrelevant to the Americans' strategic calculations in the Nordic region, where the Swedish Armed Forces were seen as a vital complement to NATO's defenses. ${ }^{\text {cliv }}$ Consequently, it remained in the U.S.'s best interests to continue to buttress Sweden's military capacity, especially at a time when many of its official European allies were curtailing their defense spending at much sharper rates than the Swedes. ${ }^{\text {clv }}$ If anything, for the U.S. the import of the Swedish Armed Forces grew in these years as Washington desperately wanted to reduce its own military expenditures in Europe. ${ }^{\text {clvi }}$

Strategic realities thus ultimately outweighed the Americans' displeasure with the Social Democratic administration's Vietnam criticism, which was tolerable to Washington so long as Stockholm remained firmly anchored to the Western camp in Europe. The détente had done much to loosen the U.S.'s grip over Western Europe, and as a result it was forced to put up with a level of dissent that would have been unthinkable only a decade earlier. Sweden's conduct in this instance therefore not only serves as a valuable reminder about the limits of American power, but it also underscores that in this period the final outcome of the East-West standoff was by no means certain in the minds of many West Europeans. Since the end of the Cold War this fact is all too often forgotten.

\footnotetext{
${ }^{\mathrm{i}}$ For an overview of West European foreign relations during the détente, see Richard Davy (ed.), European Détente: A reappraisal (London: Sage Publications, 1992); Gregory Flynn and Richard Greene (eds.), The
} 
West and the Soviet Union (New York: St. Martin's Press, 1990), and Kenneth Dyson (ed.), European Détente: Case studies of the politics of East-West relations (New York: St. Martin's Press, 1986).

${ }^{\text {ii }}$ More than any other Social Democratic leader, Palme is personally associated with this policy. He first challenged publicly the American war effort in July 1965, thus well prior to becoming Prime Minister in September 1969. Magnus Jerneck, 'Olof Palme - en internationell propagandist,' in Bo Huldt and Klaus Misgeld (eds.), Socialdemokratin och svensk utrikespolitik (Göteborg: M H Publishers, 1990), p.130.

iii 27 Feb. 1969. Scandinavian Desk Dept. of State. Paul Hughes. Confidential Memo. "Briefing Paper Sweden.” Folder: Political \& Defense. Sweden, Box \# 2506, RG 59; Undated (ca April 1970). European Section Dept. of State. Unsigned. Secret Memo. "Briefing Material Ambassador Holland's Arrival in Stockholm - April 1970." Folder: Political \& Defense. Sweden, Box \# 2610, RG 59. See also remarks by Senator, Stephen Young Congr. Rec. 91st Congr., 1st Sess., 13 Oct. 1969: 29623.

iv International scholars agree that, in hindsight, Swedish Social Democracy has become the principal symbol of West European dissent against the war. Thomas Schlesinger, The United States and the European Neutrals (Vienna: Braumüller, 1991), p.89; Efraim Karsh, Neutrality and Small States (New York: Routledge, 1988), pp.120-121, 164; and Alastair Parker, 'International Aspects of the Vietnam War,' in Peter Lowe (ed.), The Vietnam War (New York: St. Martin's Press, 1998), pp.211-212.

${ }^{v}$ The SAP leadership repeatedly discussed this issue. VU protokollet 10 Feb. 1968; SAP

Riksdagsgruppensprotokoll 21 April 1970.

vi Birgitta Dahl, 'Solidaritetsarbetet för Vietnam,' in Enn Kokk (ed.), Var blev ni av ljuva drömmar? (Stockholm: Ordfront, 2002), pp.184-185. For a specific illustration, see Social Democratic Foreign Minister Torsten Nilsson's remarks as cited in Arbetet 24 Oct. 1967.

vii Olof Ruin, I välfärdsstatens tjänst (Stockholm: Tidens Förlag, 1986), pp.307-308. For a specific illustration, see editorial in Tiden, \# 6 1965, pp.321-325.

viii Yngve Möller, Sverige och Vietnamkriget (Stockholm: Tidens Förlag, 1992), pp.252, 255; and Ulf Bjereld and Marie Demker, Utrikespolitiken som slagfält (Stockholm: Nerenius \& Santérus Förlag, 1995), pp.304, 371.

${ }^{i x}$ Bo Huldt, Sweden, the United Nations, and Decolonization (Lund: Esselte Stadium, 1974), pp.29-33; and Kaj Björk, Vägen till Indokina (Stockholm: Atlas, 2003), p.208.

${ }^{x}$ Frédéric Bozo, Two Strategies for Europe: De Gaulle, the United States, and the Atlantic Alliance (New York: Rowman \& Littlefield Publishers, 2001), p.187; and Fredrik Logevall, Choosing War (Berkeley: University of California Press, 1999), p.15.

${ }^{x i}$ The following are the most important works in this category: Leif Leifland, Frostens år (Stockholm: Nerenius \& Santérus Förlag, 1997); Fredrik Logevall, 'The Swedish-American Conflict over Vietnam,' Diplomatic History 1993 17(3), pp.421-445; Yngve Möller, Sverige och Vietnamkriget (Stockholm: Tidens Förlag, 1992); Magnus Jerneck, Kritik som utrikespolitiskt medel. En studie av de amerikanska reaktionerna på den svenska Vietnamkritiken (Lund: Dialogus, 1983).

xii To date, only one article has appeared on this subject. Christer Jönsson \& Bo Petersson, 'The Bear and the Mouse that Roared: Soviet Reactions to Public Swedish Criticism - Czechoslovakia and Vietnam,' Cooperation and Conflict 1985 20(2), pp.79-90.

xiii Nils Andrén, 'Istället för syntes,' in Socialdemokratin och svensk utrikespolitik, pp.214-215, 220; and Bo Huldt, 'Socialdemokratin och säkerhetspolitiken,' in Socialdemokratin och svensk utrikespolitik, pp.171-173.

xiv Ann-Marie Ekengren, Av hänsyn till folkrätten? (Stockholm: Nerenius \& Santérus Förlag, 1999), pp.238-242, 273-289, 299, 302-304.

${ }^{\mathrm{xv}}$ Leifland, Frostens år, pp.156-157. For specific illustrations, see Tage Erlander's remarks in the First Chamber of parliament on 21 March 1968 (Riksdagsprotokollet, \# 13, 21 March 1968, p.45.), or Social Democratic Foreign Minster Krister Wickman's address to the parliament on 23 March 1972 (Riksdagsprotokollet, \# 47, 23 March 1972, pp.7-8.) U.S. officials readily recognized that SwedishAmerican tensions over Indochina did not prevent the two countries from seeing eye to eye on most European issues. 11 June 1969. Turner Cameron Jr. Memo. "U.S. Policy Assessment - Sweden 1969." Folder: Political \& Defense. Sweden, Box \# 2505, RG 59; 28 Jan. 1972. Bureau of Intelligence and Research Dept. of State. Unsigned. Memo. Folder: Political \& Defense. Sweden, Box \# 2611, RG 59.

${ }^{\mathrm{xvi}}$ In these years, Swedish foreign policy, for instance, also distinguished itself by taking a strong stance in favor of Marxist-oriented movements of national liberation in southern Africa. Ove Nordenmark, Aktiv utrikespolitik - södra Afrika 1969-1987 (Stockholm: Almqvist \& Wiksell, 1991); and Tor Sellström, 
Sweden and National Liberation in Southern Africa Vol II: Solidarity and Assistance (Uppsala: Nordiska Afrikainstitutet, 2002).

${ }^{\text {xvii }}$ Kent Zetterberg, 'Det strategiska spelet,' in Lars Wedin and Gunnar Åselius (eds.), Mellan Byråkrati och stridskonst (Stockholm: Försvars Högskolan, 1999), pp.33-34. For a specific illustration, see interview with Torsten Nilsson as cited in Arbeiderbladet (Oslo) 27 April 1968. Nilsson stressed the necessity of maintaining the geo-strategic status quo in the Nordic region, making clear that Sweden preferred that both Norway and Denmark remain in NATO.

xviii Remarks by Sverker Åström, the Swedish Undersecretary of State 1972-1977, as cited by Möller, Sverige och Vietnamkriget, p.274.

xix The USSR was by no means ignorant of this reality. Bo Petersson, Med Moskvas ögon (Stockholm: Arena, 1994), pp.139-148.

xx 24 Jan. 1966. Hubert de Besche. Memo. Re: Meeting with Leonard Unger, the Director of the SE Asia Section Dept. of State, on 24 Jan. 1966. UD. Avd. HP Grupp 1. Mål Ua. Politik Allmänt. Förenta Staterna. \# 213.

${ }^{x x i}$ Zetterberg, 'Det strategiska spelet,' pp.16-18, 37-39. Social Democratic leaders made no secret of this fact. See, for instance, Torsten Nilsson, Utanför protokollet (Stockholm: Tidens Förlag, 1986), pp.385, 391. xxii Gunnar Hägglöf, Minnen inför framtiden (Stockholm: Nordstedts, 1975), pp.269-270.

${ }^{x x i i i}$ Bengt Wallerfelt, Si vis pacem - para bellum (Stockholm: Probus Förlag, 1999), pp.27-28; and Fred och säkerhet. Svensk säkerhetspolitik 1969-1989 (SOU 2002: 108), pp.129, 168-170.

${ }^{\text {xxiv }}$ Riksdagsprotokollet 1972. Försvarsutskottets betänkande, \# 17 1972, p.5. This general development was also a frequent subject of Swedish diplomatic reports. 8 Nov. 1968. Swedish UN Delegation New York. Ingemar Hägglöf. Memo. Re: Undated recent conversation with Sherman Cooper, Republican Senator from Kentucky. UD. Avd. HP Grupp 1. Mål Ua. Politik Allmänt. Förenta Staterna. \# 225; 22 Oct. 1970. Charge d'affairs Swedish Embassy Washington. Leif Leifland. Memo. Re: Today's conversation with Raymond Garhoff, Security Expert Dept. of State. UD. Avd. HP Grupp 1. Mål Ua. Politik Allmänt. Förenta Staterna. \# 237; 24 April 1973. Leif Leifland. Memo. Re: Recent undated conversations with various unidentified U.S. Security Experts. UD. Avd. HP Grupp 1. Mål Ua. Politik Allmänt. Förenta Staterna. \# 259.

${ }^{\mathrm{xxv}}$ Hans Christian Cars, et al., Svensk försvarspolitik under efterkrigstiden (Stockholm: Probus Förlag, 1986), p.46.

${ }^{x x v i}$ Fred och säkerhet. Svensk säkerhetspolitik 1969-1989, pp.168-178, 203-204.

${ }^{x x v i i}$ Wallerfelt, Si vis pacem - para bellum, pp.27-28.

xxviii Torsten Nilsson's address to Gävle Arbetarekommun on 21 Jan. 1967 (transcript in UD archive.) See also editorials in the SAP's monthly publication Tiden, \# 9 1966, pp.513-516. \& \# 6 1968, pp.346-347.

xxix Torsten Nilsson, 'Vår utrikespolitik,' in Nu gäller det 70-talet. Sju tal från partikongress - 69 (Stockholm: SAP, 1969), p.33; Krister Wickman's address in Helsinki on 4 July 1973 (transcript in UD archive.) See also Olof Palme's speech at Storlien on 2 Feb. 1970 as cited in UD, Utrikesfrägor 1970, pp.822.

${ }^{\mathrm{xxx}}$ Wilhelm Agrell, Fred och fruktan. Sveriges säkerhetspolitiska historia 1918-2000 (Stockholm: Historiska Media, 2000), pp.155-156, 159-160; and Cars, et al., Svensk försvarspolititk, pp.13-15, 61. xxxi 8 July 1966. U.S. Ambassador to Sweden 1961-1967. J. Graham Parsons. Confidential telegram to State. Folder: Political \& Defense. Sweden, Box \# 2678, RG 59; 2 June 1967. Political Counselor U.S. Embassy Stockholm. Jerome K. Holloway. Confidential Briefing Memo. Folder: Political \& Defense. Sweden, Box \# 2504, RG 59; 5 March 1971. Unsigned. U.S. Embassy Stockholm. Secret Telegram to State. Folder: Political \& Defense. Sweden, Box \# 2610, RG 59; 14 July 1972. Bureau of Intelligence and Research Dept. of State. Unsigned. Secret Memo. Folder: Political \& Defense. Sweden, Box \# 2611, RG 59.

xxxii 16 June 1967. U.S. Ambassador to Sweden 1967-1969. William W. Heath. Confidential telegram to State. “U.S. Policy Assessment - Sweden 1967." Folder: Political \& Defense. Sweden, Box \# 2504, RG 59; Undated (ca April 1970). Unsigned. European Section Dept. of State. Secret Memo. "Briefing Material for Ambassador Holland's Arrival in Sweden - April 1970.” Folder: Political \& Defense. Sweden, Box \# 2610, RG 59; 31 July 1972. Executive Secretary Dept. of State. Theodore Eliot, Jr. Memo to Brig. General John M. Dunn, Office of the Vice President., Folder: Sweden, NSC Files, Box \# 707, Nixon Project.

xxxiii Alexandra Friedrich, 'Awakenings. The Impact of the Vietnam War on West German-American Relations in the 1960's' (Unpublished Ph.D. dissertation, Temple University, 2000), p.225; Robin Laird and Phil Williams, 'Western Security Policy Toward the Soviet Union: Problems of Unity and Diversity,' 
in The West and the Soviet Union, pp.229-230, 241-242; and Lawrence Kaplan, NATO and the United States: The Enduring Alliance (New York: Twayne Publishers, 1994), p.109.

xxxiv John Van Oudenaren, Détente in Europe (London: Duke University Press, 1991), pp.73-81; and Harto Harkovirta, East-West Conflict and European neutrality (Oxford, UK: Claredon Press, 1988), pp.213-225.

${ }^{\mathrm{xxxv}}$ Hans Lödén, För säkerhetens skull (Stockholm: Nerenius \& Santérus Förlag, 1999), pp.378-380.

${ }^{x x x v i}$ Derek Urwin, Western Europe Since 1945 (New York: Longman, 1981), pp.268-269.

xxxvii Nils Andrén, Den totala säkerhetspolitiken (Stockholm: Rabén \& Sjögren, 1972), pp.80-81.

${ }^{x x x v i i}$ For specific illustrations, see Torsten Nilsson's speech to the SAP Congress on 30 Sept. 1969 (SAP

Kongressprotokoll. 24:e Kongressen. 28 Sept.- 4 Oct. 1969, p.243.), or Krister Wickman's address to the SAP Congress on 6 Oct. 1972 (SAP Kongressprotokoll. 25:e Kongressen. 1-7 Oct. 1972, pp.842-844.)

xxxix Olof Palme's comments as cited in Gotlands Folkblad 27 Jan. 1973; Krister Wickman's speech in Kalmar on 20 Aug. 1973 (transcript in UD archive.)

${ }^{\mathrm{xl}}$ For specific illustrations, see Torsten Nilsson's remarks in the Second Chamber of parliament on 24 March 1965 (Riksdagsprotokollet, \# 13, 24 March 1965, p.30.) and on 9 Dec. 1965 (Riksdagsprotokollet, \# 40, 9 Dec. 1965, pp.5-6.), or Tage Erlander's speech to Metalindustriarbetareförbundet on 18 Aug. 1965 as cited by Torsten Nilsson, Ater Vietnam (Stockholm: Tidens Förlag, 1981), pp.52-53.

xli 20 Jan. 1967. J. Graham Parsons. Confidential telegram to State. Folder: Political \& Defense. Sweden, Box \# 2504, RG 59; 16 Oct. 1971. Chargé d'affairs U.S. Embassy Stockholm. John Guthrie. Telegram to State. Folder: Political \& Defense. Sweden, Box \# 2610, RG 59; 25 Oct. 1972. U.S. Embassy Stockholm. Unsigned. Telegram to State. Re: "The $25^{\text {th }}$ SAP Congress - Oct. 1972." Folder: Political \& Defense. Sweden, Box \# 2611, RG 59.

xlii Jan Pierre, Partikongresser och regeringens politik (Lund: Kommunalfakta Förlag, 1986), p.247; and Huldt, 'Socialdemokratin och säkerhetspolitiken,' pp.169-173.

xliii Fred och säkerhet. Svensk säkerhetspolitik 1969-1989, pp.38, 509-510, 609-613; and Wallerfelt, Si vis pacem - para bellum, pp.165-168.

xliv This development was not lost upon contemporary commentators. See, for example, editorial in Dagens Nyheter 31 March 1968.

${ }^{x l v}$ At a minimum, it is clear that Sweden's new strategic doctrine was largely adopted for the simple reason that it justified sharply reduced defense expenditures. Cars, et al., Svensk försvarspolititk, pp.13-15; and Joseph Kruzel, 'Sweden's Security Dilemma: Balancing domestic realities with the obligations of neutrality,' in Bengt Sundelius (ed.), The Committed Neutral: Sweden's Foreign Policy (Bolder, CO: Westview Press, 1989), p.73.

${ }^{x l v i}$ Mikael af Malmborg, Neutrality and State Building in Sweden (New York: Palgrave, 2001), p.159.and Huldt, 'Socialdemokratin och säkerhetspolitiken,' pp.169-173.

xlvii Hanspeter Neuhold, 'The Austrian View' in European Détente: A reappraisal, p.215.

xlviii 11 May 1965. J. Graham Parsons. Confidential telegram to State. Re: Today's meeting with Leif

Belfrage, Political Section UD. Folder: Political \& Defense. Sweden, Box \# 2678, RG 59; 23 Feb. 1966. Swedish Ambassador to the U.S. 1963-1972. Hubert de Besche. Memo. UD. Avd. HP Grupp 1. Mål Ua. Politik Allmänt. Förenta Staterna. \# 214; 20 Sept. 1969. Political Section UD. P.B. Kollberg. Memo; 27 March 1973. Leif Leifland. Memo. UD. Avd. HP Grupp 1. Mål Ua. Politik Allmänt. Förenta Staterna. \# 231.

xlix 25 Oct. 1968. Hubert de Besche. Memo. UD. Avd. HP Grupp 1. Mål Ua. Politik Allmänt. Förenta Staterna. \# 225; 18 Oct. 1969. P. B. Kollberg. Memo. UD. Avd. HP Grupp 1. Mål Ua. Politik Allmänt. Förenta Staterna. \# 231; 3 March 1970. Hubert de Besche. Memo. UD. Avd. HP Grupp 1. Mål Ua. Politik Allmänt. Förenta Staterna. \# 235.

${ }^{1}$ For specific illustrations, see Liberal representative Bertil von Friesen's remarks in the Second Chamber of parliament on 8 March 1967 (Riksdagsprotokollet, \# 12, 8 March 1967, p.56.), or comments by Liberal Leader Sven Wedén, and Anders Björk, the Chairman of the Conservative Youth Organization, as cited in Dagens Nyheter 19 Feb. 1968. More to the point, some within the non-socialist camp worried that Swedish Vietnam criticism was indirectly fueling the growth of neo-isolationist sentiments in the U.S. See, for example, editorial in Smålands Dagblad 14 March 1968.

li Torsten Nilsson's address to the SAP Congress on 30 Sept. 1969 as cited in UD, Utrikesfrågor 1969, p.42. For a likeminded opinion in the Social Democratic press, see editorial in Sydöstra Sveriges Dagblad 9 Jan. 1968. 
${ }^{\text {lii }}$ For specific illustrations, see either Social Democratic representative Kaj Björk's remarks in the Second Chamber of parliament on 9 Dec. 1965 (Riksdagsprotokollet, \# 40, 9 Dec. 1965, p.82.), or interviews with former Social Democratic cabinet members, Sven Andersson and Torsten Nilsson as cited by Jerneck, Kritik som utrikespolitiskt medel, p.57.

liii See, for instance, Torsten Nilsson's remarks in the Second Chamber of parliament on 23 March 1966 (Riksdagsprotokollet, \# 12, 23 March 1966, pp.28, 57.), or Bertil Bolin's commentary in Tiden, \# 8 1966, pp.497-499. This subject was repeatedly discussed in Swedish diplomatic reports. 18 March 1966. Hubert de Besche. Confidential telegram to UD. UD. Avd. HP Grupp 1. Mål Ua. Politik Allmänt. Förenta Staterna. \# 214; 25 Jan. 1967. Hubert de Besche. Confidential telegram to UD. UD. Avd. HP Grupp 1. Mål Ua. Politik Allmänt. Förenta Staterna. \# 217; 16 July 1971. Hubert de Besche. Memo. UD. Avd. HP Grupp 1. Mål Ua. Politik Allmänt. Förenta Staterna. \# 244.

liv Friedrich, 'Awakenings. The Impact of the Vietnam War on West German-American Relations in the 1960's,' p.296.

${ }^{\text {Iv }}$ Frank Costigliola, 'The Vietnam War and Challenges to American Power in Europe,' in Lloyd C. Gardner and Ted Gittinger (eds.), International Perspectives on Vietnam (College Station, TX: Texas A \& M University Press, 2000), pp.144-152.

lvi Interview with the Minister of Finance, Gunnar Sträng as cited by Nordal Åkerman, Apparaten Sverige (Stockholm: Wahlström \& Widstrand, 1970), p.72; Torsten Nilsson's remarks to the 1969 SAP Congress as cited in 'Vår Utrikespolitik,' p.33.

lvii 10 July 1969. Hubert de Besche. Memo. UD. Avd. HP Grupp 1. Mål Ua. Politik Allmänt. Förenta Staterna. \# 236; 7 Dec. 1971. Swedish Embassy Washington. Jan Eliasson. Memo. UD. Avd. HP Grupp 1. Mål Ua. Politik Allmänt. Förenta Staterna. \# 247; 18 June 1973. Leif Leifland. Memo. UD. Avd. HP Grupp 1. Mål Ua. Politik Allmänt. Förenta Staterna. \# 262.

lviii See, for instance, Torsten Nilsson's remarks in the Second Chamber of parliament on 8 March 1967 (Riksdagsprotokollet, \# 12, 8 March 1967, pp.29-31.), or his address to the SAP Congress on 30 Sept. 1969 (SAP Kongressprotokoll. 24:e Kongressen. 28 Sept.- 4 Oct. 1969, p.246.) This issue was likewise addressed by the Social Democratic parliamentary group on 21 Nov. 1972 (SAP

Riksdagsgruppensprotokoll 21 Nov. 1972.) This development was also often noted in Swedish diplomatic reports. 20 Sept. 1969. P. B. Kollberg. Memo. UD. Avd. HP Grupp 1. Mål Ua. Politik Allmänt. Förenta Staterna. \# 231; 26 Oct. 1971. Leif Leifland. Memo. Re. Today's meeting with Raymond Garthoff. UD. Avd. HP Grupp 1. Mål Ua. Politik Allmänt. Förenta Staterna. \# 246; 27 March 1973. Leif Leifland. Memo. UD. Avd. HP Grupp 1. Mål Ua. Politik Allmänt. Förenta Staterna. \# 258.

lix 1 May 1966. Hubert de Besche. Telegram to UD. UD. Avd. HP Grupp 1. Mål Ua. Politik Allmänt. Förenta Staterna. \# 215; 12 Feb. 1968. Hubert de Besche. Memo. UD. Avd. HP Grupp 1. Mål Ua. Politik Allmänt. Förenta Staterna. \# 221; 1 Feb. 1972. Hubert de Besche. Memo. UD. Avd. HP Grupp 1. Mål Ua. Politik Allmänt. Förenta Staterna. \# 249. The idea that the U.S. had shifted its attention away from Europe appears to have been widely held in Social Democratic circles. See, for instance, editorial in Tiden, \# 5 1966, pp.257-262., or article by Lennart Ljunglöf in Tiden, \# 1 1971, pp.30-35. Such concerns were also commonly voiced by the non-socialist opposition. See, for example, comments by Conservative representative Gösta Bohman in the Second Chamber of parliament on 23 March 1966 (Riksdagsprotokollet, \# 12, 23 March 1966, pp.52-53, 117-119.), or remarks by Liberal representative Olof Dahlén in the First Chamber of parliament on 21 March 1968 (Riksdagsprotokollet, \# 13, 21 March 1968, pp.20-22.) For illustrations of similar sentiments in the non-socialist press, see editorials in Sydsvenska Dagbladet 4 Nov. 1968 and Kvällsposten 28 Jan. 1973.

${ }^{1 x} 8$ Nov 1968. Hubert de Besche. Confidential telegram to UD. UD. Avd. HP Grupp 1. Mål Ua. Politik Allmänt. Förenta Staterna. \# 225; 2 March 1971. Hubert de Besche. Memo. UD. Avd. HP Grupp 1. Mål Ua. Politik Allmänt. Förenta Staterna \# 241.; 24 Oct. 1972. Leif Leifland. Memo. UD. Avd. HP Grupp 1. Mål Ua. Politik Allmänt. Förenta Staterna. \# 254. Swedish diplomats seemed to believe that Nixon personally wanted to retain a strong U.S. presence in Europe, but at the same time it was also clear that the President could not afford to ignore rising domestic pressure to reduce American defense expenditures, and therefore a gradual reduction of U.S. troops in Europe was probably inevitable.

${ }^{1 x i}$ For specific examples, see remarks by either Liberal Leader Bertil Ohlin in the Second Chamber of parliament on 23 March 1966 (Riksdagsprotokollet, \# 12, 23 March 1966, pp.39-41.), or by the new Liberal Leader Sven Wedén, and Conservative representative Leif Cassel in the Second Chamber of parliament on 21 March 1968 (Riksdagsprotokollet, \# 13, 21 March 1968, pp.89, 131.) 
1xii Comments by the Social Democratic Ambassador-designate to the U.S., Yngve Möller as cited by Dagens Nyheter 14 Jan. 1973.

lxiii 20 Oct. 1969. Jean-Christophe Öberg. Memo of Conversation. Re: Today's meeting between Torsten Nilsson, and the U.S. Secretary of State, William Rogers. UD. Avd. HP Grupp 1. Mål Ua. Politik Allmänt. Förenta Staterna. \# 232.

${ }^{\text {lxiv }}$ For a good introduction to this topic, see Noel Cary, 'Reassessing Germany's Ostpolitik Part 1: From Détente to Refreeze,' Central European History 2000 33(2), pp.235-262; and Noel Cary, 'Reassessing Germany's Ostpolitik Part 2: From Refreeze to Reunification,' Central European History 2000 33(3), pp.369-390.

lxv Gottfried Niedhart, 'The Federal Republic's Ostpolitik and the United States,' in Kathleen Burke and Melvyn Stokes (eds.), The United States and the European Alliance Since 1945 (Oxford, UK: Berg Publishers, 1999), p.303; Joachim Arenth, Johnson, Vietnam und der Westen. Transaltantische Belastungen 1963-1969 (Munich: Olzog, 1994), p.169; and Eugenie Blang, 'To Urge Common Sense on the Americans' (Unpublished Ph.D. dissertation, College of William and Mary, 2000), pp.2-3, 113, 173.

${ }^{\text {lxvi }}$ Walter Laqueur, Europe in Our Time (New York: Penguin, 1992), pp.334-337; Wolfram Hanreider, 'The Federal Republic, the United States and the New Europe,' in Robert Jordan (ed.), Europe and the Superpowers (New York: St. Martin's Press, 1991), pp.73-74; and Christoph Bluth, 'A West German View,' in European Détente: A Reappraisal, p.42.

lxvii Palme's remarks to the Social Democratic parliamentary group on 10 April 1973 (SAP Riksdagsgruppensprotokoll 10 April 1973.)

lxviii Clas Arvidsson, Ett annat land (Stockholm: Timbro, 1999), p.94.

lxix Jussi Hanhimäki, Scandinavia and the United States (New York: Twayne Publishers, 1997), pp.128129. Not only had the Swedes facilitated the initial contacts between Soviet officials and West German Social Democratic leaders, but they had also repeatedly reassured American officials about Willy Brandt's intentions. 13 March 1967. J. Graham Parsons. Confidential Memo. Re: Meeting with Richard HichensBergström, the Director of the Political Section of the Swedish Foreign Ministry on 10 March 1967. Folder: Political \& Defense. Sweden, Box \# 2506, RG 59. During this meeting Hichens-Bergström had apparently relayed the Swedish Social Democratic leadership's positive assessment of German Ostpolitik.

${ }^{1 x x}$ For specific illustrations, see remarks by Tage Erlander in the First Chamber of Parliament on 21 March 1968 (Riksdagsprotokollet, \# 13, 21 March 1968, p.8.), Torsten Nilsson's comments in the Second Chamber of parliament on 26 March 1969 (Riksdagsprotokollet, \# 13, 26 March 1969, p.5.), and Krister Wickman's address to the SAP Congress on 6 Oct. 1972 (SAP Kongressprotokoll. 25: e Kongressen. 1-7 Oct. 1972, pp.842-844.) See also Palme's remarks as cited in Stuttgarter Zeitung 24 Feb. 1970 and Die Welt 14 March 1970.

lxxi 15 June 1970. Willy Brandt Letter to Olof Palme; 1 Dec. 1970. Willy Brandt Letter to Olof Palme; 23 Dec. 1970. Willy Brandt Letter to Olof Palme; 23 Dec. 1970. Olof Palme Letter to Willy Brandt; 5 April 1973. Olof Palme Letter to Willy Brandt; 15 April 1973. Willy Brandt Letter to Olof Palme (SAP. Olof Palme's arkiv. 3:2 Palmes Brev Samling, vol. 051 \& 089. ARAB). In these letters, the two leaders mostly discuss the progress of German Ostpolitik, though Brandt also thanks Palme for Sweden's efforts to advance this policy.

lxxii Stephen Padget and William Patterson, A History of Social Democracy in Postwar Europe (New York: Longman, 1991), pp.238-239; and Per Carlsen, et al., 'Danish Ostpolitik 1967-1993: Breakdown of Stability - Unknown Challenges,' in Carsten Due-Nielsen and Nikolaj Petersen (eds.), Adaptation and Activism: The Foreign Policy of Denmark 1967-1993 (Copenhagen: Dansk Udenrigspolitisk Institut, 1995), p. 138 .

Ixxiii Curtis Kebble, Britain and the Soviet Union 1917-1989 (London: Macmillan), p.274; Marta Dassu, 'Italo-Soviet Relations: The Changing Domestic Agenda,' in European Détente: A reappraisal p.113; and Neuhold, 'The Austrian View,' p.215.

lxxiv Tage Erlander's remarks on Soviet television as cited in UD, Utrikesfrågor 1965, pp.40-42; Social Democratic representative Yngve Möller's address to the First Chamber of parliament on 21 March 1968 (Riksdagsprotokollet, \# 13, 21 March 1968, pp.69-70); and Torsten Nilsson's remarks as cited in Arbeiderbladet (Oslo) 27 April 1968.

${ }^{\text {lxxv }}$ Editorials in Veckans Affärer, \# 44 1969, pp.52-57. and Svensk Export, \# 13 1969, pp.3-4. \& \# 141969 , p.20. 
${ }^{\text {Ixxvi }}$ Articles in the Hindustan Times 24 Jan. 1969 and Washington Post 20 Feb. 1969. See also remarks by House representative Robert Price, Congr. Rec. 93 ${ }^{\text {rd }}$ Congr., $1^{\text {st }}$ Sess., 3 Aug. 1973: 28265.

lxxvii See, for instance, editorial in the Saigon Daily 17 Jan. 1969, or columns by Scott Aiken in the Cincinnati Enquirer 20 Feb. 1969, Ronald Huntford in the Washington Post 21 Feb. 1969, and William Frye in the Ontario Star 19 Aug. 1972.

${ }_{\text {lxxviii }}$ Remarks by House representative, Philip Crane, Congr. Rec. $93^{\text {rd }}$ Congr., $1^{\text {st }}$ Sess., 8 March 1973: 7234-7236; U.S. House of Representatives. House Committee on Foreign Affairs. Report of the Special Study Mission of the Subcommittee on Europe. 'Soviet Union and Scandinavia.' $90^{\text {th }}$ Congr., $1{ }^{\text {st }}$ Sess., 13 Nov. 1967: 10-11.

lxxix 24 May 1972. U.S. Ambassador to Sweden 1970-1972. Jerome Holland. Confidential telegram to State. Folder: Political \& Defense. Sweden, Box \# 2611, RG 59; 23 Aug. 1972. Jerome Holland. Confidential telegram to State. "U.S. Policy Assessment - Sweden 1972." Folder: Political \& Defense. Sweden, Box \# 2611, RG 59.

Ixxx 10 August 1965. J. Graham Parsons. Confidential Telegram to State. Folder: Political \& Defense. Sweden, Box \# 2677, RG 59; 8 Dec. 1967. William W. Heath. Confidential telegram to State. Re: Torsten Nilsson's recent trip to Moscow. Folder: Political \& Defense. Sweden, Box \# 2506, RG 59; Undated (ca April 1970). European Section Dept. of State. Unsigned. Secret Memo. "Briefing Material for Ambassador Holland's Arrival in Stockholm - April 1970.” Folder: Political \& Defense. Sweden, Box \# 2610, RG 59; 20 June 1970. Secretary of State. William Rogers. Secret Memo to the President. Folder: Sweden, NSC Files, Box \# 707, Nixon Project; 31 Aug. 1972. Chargé Affairs U.S. Embassy Stockholm. John C. Guthrie. Confidential telegram to State. Folder: Political \& Defense. Sweden, Box \# 2611, RG 59.

lxxxi 17 Aug. 1967. Jerome Holloway. Memo to Paul Hughes, Scandinavian Desk Dept of State. Folder: Political \& Defense. Sweden, Box \# 2506, RG 59; 2 Nov. 1967. European Section Dept of State. John Leddy. Memo. Re: Undated meeting with Hubert de Besche, regarding the Swedish Prime Minister's recent visit to the USSR. Folder: Political \& Defense. Sweden, Box \# 2506, RG 59; 15 Nov. 1969. Turner Cameron, Jr. Confidential telegram to State. Re: "Relations with Communist countries." Folder: Political \& Defense. Sweden, Box \# 2506, RG 59. Cameron notes that in the last few years Sweden has vastly expanded its contacts with the Eastern bloc states as well as with Communist movements in the Third World. 24 May 1972. Jerome Holland. Confidential telegram to State. Folder: Political \& Defense. Sweden, Box \# 2611, RG 59; 16 July. 1972. Jerome Holland. Confidential telegram to State. Re: "Politics and Policy in Sweden - Spring 1972." Folder: Political \& Defense. Sweden, Box \# 2611, RG 59.

lxxxii Sweden's opening to the East had tentatively gotten underway in 1964, when Nikita Khrushchev made an official state visit to Stockholm, and this was followed the next year by Tage Erlander's return visit to Moscow. Swedish Ostpolitik, however, cannot really be said to have gained any substantial momentum until 1967, at which time Social Democratic leaders traveled to Bulgaria, Rumania, Poland, and the USSR. These official visits were supplemented by two lower level trips to the German Democratic Republic. For a broader overview of intensified Swedish-Soviet diplomatic exchanges in this period, see Bo Petersson, Sovjetunionen och neutraliteten i Europa (Göteborg: M. H. Publishing, 1989), p.50; and Gunnar Jarring, Utan glasnost och perestrojka (Stockholm: Bonniers, 1989), pp.76-103.

lxxxiii Fred och säkerhet. Svensk säkerhetspolitik 1969-1989, pp.133-134.

lxxxiv 28 Jan. 1972. Bureau of Intelligence and Research. Dept. of State. Unsigned. Memo. Re: "Swedish Foreign Minister bound for Moscow.” Folder: Political \& Defense. Sweden, Box \# 2611, RG 59. The memo highlights the Swedish government's apparent unwillingness to protest the Soviets' negative reaction to the awarding of the Nobel Prize to Alexander Solzhenitsyn.

${ }^{\text {lxxxv }}$ For a contemporary example, see Fria Moderata Studentförbundet, Sverige landet som klev ut $i$ kylan (Skara: [n.p.],1972), pp.48-49. For a more recent illustration, see Per Ahlmark, Vänstern och tyranniet (Stockholm: Timbro, 1994).

lxxxvi Jan Linder, Sverige i skottlinjen (Stockholm: Infomanager Förlag), pp.88-89; and Kenneth Olsson, Affärenas Sverige (Stockholm: Contra Förlag, 1993), p.165. See also op-ed by Thomas Gür in Svenska Dagbladet 9 Aug. 1998.

lxxxvii af Malmborg, Neutrality and State Building in Sweden, pp.159-160, 162, 169. See also op-ed by Svante Nordin in Svenska Dagbladet 14 Oct. 1999.

lxxxviii Geoffrey Williams, The Permanent Alliance (Leyden: A. W. Sijthoff, 1977), p.343; and Karsh, Neutrality and Small States, p.164. 
${ }^{\text {lxxxix }}$ Petersson, Sovjetunionen och neutraliteten i Europa, pp.55-59; and Jarring, Utan glastnost och perestrojka, pp.91-103.

${ }^{\mathrm{xc}}$ Daniel Wiklund, Spelet om frihandelsavtalet (Stockholm: Rabén \& Sjögren, 1977), pp.178-184.

${ }^{x c i}$ For specific illustrations, see Tage Erlander's remarks on Soviet television as cited in UD, Utrikesfrågor 1965, pp.40-42; and Torsten Nilsson's address to the Second Chamber of parliament on 29 Oct. 1969 as cited in UD, Utrikesfrågor 1969, p.62.

xcii Ulf Bjereld, Kritiker eller medlare? (Stockholm: Nerenius \& Santérus Förlag, 1992), pp.73, 47-53, 169.

${ }^{x i i i}$ Ann-Sofie Nilsson, Den moraliska stormakten (Stockholm: Timbro, 1991), pp.16, 29-36; Jerneck, “Olof Palme - en internationell propagandist,' p.134; and Möller, Sverige och Vietnamkriget, p.365.

${ }^{x c i v}$ Marianna Sullivan, France's Vietnam Policy (London: Greenwood Press, 1978), p.16; and Caroline Page, US Official Propaganda during the Vietnam War: The limits of persuasion (London: Leicester University Press, 1996), p.179. Just like in the Swedish case, Page notes that the French-American conflict over Vietnam did not effect the two countries' collaboration in most other areas.

${ }^{\mathrm{xcv}}$ Undated (ca June/July 1972). John Owens. Memo to Scott George, European Section Dept. of State. Folder: Political \& Defense. Sweden, Box \# 2611, RG 59. The memo calls attention to Olof Palme's habit of ignoring Soviet transgressions, while at the time consistently making a point to condemn America's conduct. 23 Aug. 1972. Jerome Holland. Confidential telegram to State. "U.S. Policy Assessment - Sweden 1972.” Folder: Political \& Defense. Sweden, Box \# 2611, RG 59.

${ }^{x c v i}$ Remarks by Liberal Leader, Sven Wedén in the Second Chamber of parliament on 21 March 1968 (Riksdagsprotokollet, \# 13, 21 March 1968, pp.29-30.); Comments by the former Chairman of the Liberal Party, Bertil Ohlin in the Second Chamber of parliament on 29 April 1970 (Riksdagsprotokollet, \# 21, 29 April 1970, pp.89-92.) Such complaints were also frequently heard in the non-socialist press. Editorials in Sundsvalls Tidning 23 Feb. 1968, Göteborgs handels- och sjöfartstidning 28 Dec. 1972, and Dagen 2 Jan. 1973.

xcvii Ulf Nilsson, Sluten anstalt (Stockholm: Komintern Instant Media, 1998), pp.208-212; and Bertil Östergren, Vem är Olof Palme? (Stockholm: Timbro, 1984), pp.298-312.

xcviii Sten Andersson's remarks as cited in Svenska Dagbladet 23 Aug. 1998.

${ }^{x i x}$ For a specific example, see Conservative Leader Yngve Holmberg's remarks in the First Chamber of parliament on 21 March 1968 (Riksdagsprotokollet, \# 13, 21 March 1968, pp.36-37.)

${ }^{\mathrm{c}}$ For specific illustrations, see either editorial in Vimmerby Tidning 31 May 1967, or comments by Conservative politicians Anders Wijkman and Anders Björk as cited in Dagens Nyheter 24 May 1972.

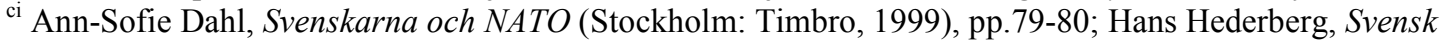
roulett (Stockholm: Legenda, 1989), pp.44-45; and af Malmborg, Neutrality and State Building in Sweden, p.169.

${ }^{\text {cii }}$ For specific illustrations, see editorials in Vimmerby Tidning 10 Jan. 1969 and Nya Wermlands Tidningen 13 Jan. 1969, or Leif Cassel, Så vitt jag minns (Stockholm: Askil \& Kärnakull, 1973), pp.195-198; and interview with Gösta Bohman as cited by Tom Alandh and Birgitta Zachrisson, Berättelser om Palme (Stockholm: Nordstedts, 1999), p.193.

ciii Articles in the Washington Post 14 Sept. 1967, Il Tempo 12 March 1968, and Houston Post 13 Sept. 1968, or column by H. A. Lundof in Elseviers Weekblad 20 April 1968 as cited in UD, Sverige i Utlänsk press 1968 , pp.10-11.

civ 16 July. 1972. Jerome Holland. Confidential telegram to State. Re: "Politics and Policy in Sweden Spring 1972.” Folder: Political \& Defense. Sweden, Box \# 2611, RG 59.

${ }^{\mathrm{cv}}$ Remarks by House representative, John Rarick, Congr. Rec. $91^{\text {st }}$ Congr., ${ }^{\text {st }}$ Sess., 3 Oct. 1969: $28583-$ 28584; and Senator Herman Talmadge, Congr. Rec. $91^{\text {st }}$ Congr., $2^{\text {nd }}$ Sess., 27 Jan 1970: 1275-1276.

${ }^{\text {cvi }}$ Olof Palme's May $1^{\text {st }}$ speech in 1966 as cited in Olof Palme, Politik är att vilja (Stockholm: Prisma, 1968), pp.184-189; and Olof Palme's remarks as cited in Kvällsposten 10 March 1968.

cvii Lars Svedgård, Palme en presentation (Stockholm: Rabén \& Sjögren, 1970), pp.79, 87-99; Hans Haste, Boken om Palme (Stockholm: Tiden, 1986), pp.44-45; and Sverker Åström, Ögonblick (Stockholm:

Bonnier Alba, 1992), p.212.

cviii Olof Palme speech as cited in "Socialdemokratin inför 70-talet" in Nu gäller det 70-talet (Stockholm:

SAP, 1969), p.95; and interview with Olof Palme as cited in Time Magazine 29 Jan. 1973.

${ }^{\mathrm{cix}}$ Hakovirta, East-West Conflict and European Neutrality, pp.161-164, 169-170.

${ }^{\mathrm{cx}}$ Bjereld, Kritiker eller medlare?, pp.73, 47-53, 169. Social Democratic criticism of the Soviet Union in this period tended to appear mostly in conjunction with Swedish election campaigns. 
${ }^{\text {cxi }}$ When Olof Palme visited Moscow in June 1970, the Czechoslovakian invasion apparently was never even broached. Jarring, Utan glastnost och perestrojka, pp.91-103.

cxii Jönsson and Petersson, 'The Bear and the Mouse that Roared: Soviet Reactions to Public Swedish Criticism - Czechoslovakia and Vietnam,' p.88. Only a year after the Swedish condemnation of the Soviet invasion of Czechoslovakia, Torsten Nilsson and Viktor Maltev, the Soviet Ambassador to Sweden, agreed that: "Swedish-Soviet relations could hardly be better." 19 Aug. 1969. Jean-Christophe Öberg. Memo. Re: Today's meeting between Torsten Nilsson and Viktor Maltev. UD. Avd. HP Grupp 1. Mål Er. Politik Allmänt. Sovjet unionen. \# 318.

cxiii Jönsson and Petersson, 'The Bear and the Mouse that Roared: Soviet Reactions to Public Swedish Criticism - Czechoslovakia and Vietnam,' p.80.

${ }^{\text {cxiv }}$ Hakovirta, East-West Conflict and European Neutrality, p.169.

${ }^{\mathrm{cxv}}$ Kaj Björk's remarks to the SAP leadership on 26 Nov. 1970 (PS protokollet 26 Nov. 1970.)

cxvi Krister Wahlbäck, 'Från medlare till kritiker,' Internationella Studier 1973 (3), p.93.

cxvii On earlier occasions, the Soviets had demonstrated the ability to interpret accurately the domestic motives behind the Social Democrats' foreign policy manifestations. Petersson, Med Moskvas ögon, p.145.

cxviii Jönsson and Petersson, 'The Bear and the Mouse that Roared: Soviet Reactions to Public Swedish Criticism - Czechoslovakia and Vietnam,' pp.83, 86.

cxix Ibid., p.80.

cxx Jarring, Utan glasnost och perestrojka, pp.91-103.

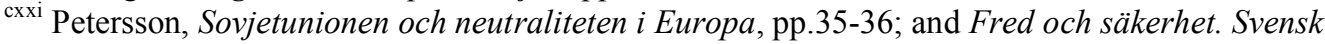
säkerhetspolitik 1969-1989, pp.155-159, 166-167.

cxxii Jarring, Utan glasnost och perestrojka, pp.85-91.

cxxiii Fred och säkerhet. Svensk säkerhetspolitik 1969-1989, pp.132-136. See, for instance, Soviet expressions of appreciation for Swedish neutrality as cited in UD, Utrikesfrågor 1970, pp.227-231; and UD, Utrikesfrågor 1972, pp.290-293.

${ }^{\text {cxxiv }}$ For specific illustrations, see articles about Alexei Kosygin's 1968 visit to Stockholm in Ny Dag 18 July 1968 and Dagens Nyheter 10 July, 12 July, 14 July 1968, or articles about Kosygin's return visit to Sweden in April 1973 in Svenska Dagbladet 3 April 1973 and Dagens Nyheter 3 April 1973. Olof Palme underscored this newfound amicability between Stockholm and Moscow during his address to the Social Democratic parliamentary group on 10 April 1973. (SAP Riksdagsgruppensprotokoll 10 April 1973.)

${ }^{\text {cxxv }}$ Alexander Kan, Sverige och Ryssland (Stockholm: Almqvist \& Wiksell, 1996), pp.140-144; and Petersson, Sovjetunionen och neutraliteten i Europa, pp.32-35, 38-39, 50-51.

cxxvi Jerneck, 'Olof Palme - en internationell propagandist,' p.134.

cxxvii Bertil Nygren, Distant Mirrors (Stockholm: Utrikespolitiska Institutet, 1991), pp.34, 42-45, 59, 64-66; af Malmborg, Neutrality and State Building in Sweden, pp.162-165; and Fred och säkerhet. Svensk säkerhetspolitik 1969-1989, pp.44-47, 146-161, 217-219, 751-757.

cxxviii Petersson, Med Moskvas ögon, pp.139-148.

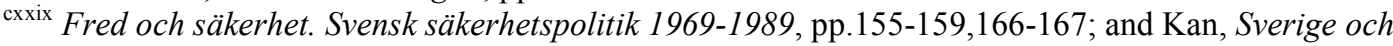
Ryssland, p.143. For specific illustrations, see either Alexei Kosygin's remarks as cited in Dagens Nyheter 12 July 1968 and 3 April 1973, or Nikolaj Nejland, 'Det aktiva Sverige,' Internationella Studier 1976 (1), pp.35-36. According to the Swedish Ambassador to the USSR, Gunnar Jarring, Soviet press treatment of Sweden in recent years - - though infrequent - - had been generally positive. 16 March 1973. Gunnar Jarring. Memo. UD. Avd. HP Grupp 1. Mål Er. Politik Allmänt. Sovjet unionen. \# 348.

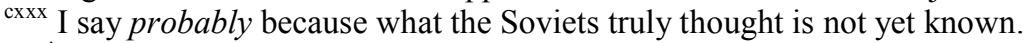

cxxxi Jönsson and Petersson, 'The Bear and the Mouse that Roared: Soviet Reactions to Public Swedish Criticism - Czechoslovakia and Vietnam,' pp.81-87. This supposition is largely based on the Soviet media's noticeable failure to highlight Olof Palme's strident criticism of the 1972 Christmas bombings of the DRV. In private, however, Soviet officials praised Palme's denunciation of the U.S. 30 Jan. 1973. Gunnar Jarring. Confidential telegram to UD. Re: Yesterday's meeting between the Soviet Vice Prime Minister, Mr. Mazurov and the Social Democratic cabinet member, Sven Aspling in Moscow. UD. Avd. HP Grupp 1. Mål Er. Politik Allmänt. Sovjet unionen. \# 347; 27 Feb. 1973. Rune Nyström. Memo. Re: Today's meeting between Foreign Minister Krister Wickman and Mikhail Jakovlev, the Soviet Ambassador to Sweden. UD. Avd. HP Grupp 1. Mål Er. Politik Allmänt. Sovjet unionen. \# 348.

${ }^{\text {cxxxii }}$ For specific examples, see articles about the withdrawal of the American Ambassador from Stockholm in Pravda 10 March, 14 March 1968, Neues Deutchland(GDR) 10 March, 14 March 1968, Izvestija 11 
March, 15 March, 1 April 1968 and Trybuna Ladu (Poland) 24 Feb., 21 April 1968 as cited in UD, Sverige $i$ Utlänsk press 1968, pp.19, 22., or articles about Swedish economic aid to the DRV in Trybuna Ladu 5 Oct. 1969, Pravda 22 Oct. 1969, Izvestija 23 Oct. 1969 and Novoja Vromja 28 Oct. 1969 as cited in UD, Sverige i Utlänsk press 1969, pp.25-26, 29. This subject was also often addressed in Swedish diplomatic dispatches. 21 Aug. 1965. Swedish Embassy Moscow. Unsigned. Telegram to UD. UD. Avd. HP Grupp 1. Mål Er. Politik Allmänt. Sovjet unionen. \# 284; 12 May 1966. Press Attaché Swedish Embassy Moscow. Martin Hallqvist. Telegram to UD. UD. Avd. HP Grupp 1. Mål Er. Politik Allmänt. Sovjet unionen. \# 290; 17 Jan. 1969. Gunnar Jarring. Memo. Re: Article in the January number of Novoja Vromja. UD. Avd. HP Grupp 1. Mål Er. Politik Allmänt. Sovjet unionen. \# 312; Undated (ca Nov. 1971). Charge d'affairs Swedish Embassy Moscow. Lennart Westerberg. Telegram to UD. Re: Article in Izvestija 27 Nov 1971. UD. Avd. HP Grupp 1. Mål Er. Politik Allmänt. Sovjet unionen. \# 371; 31 Jan. 1973. Gunnar Jarring. Telegram to UD. Re: Article in today's Pravda about American attempts to silence Sweden. UD. Avd. HP Grupp 1. Mål Er. Politik Allmänt. Sovjet unionen. \# 347. See also Kan, Sverige och Ryssland, p.143. cxxxiii Articles and editorials in Izvestija 11 Jan. 1969, Neues Deutchland 11 Jan., 13 Jan. 1969, Pravda 11 Jan., 12 Jan. 1969, Trybuna Ladu 12 Jan. 1969, Glos Porcy (Poland) 13 Jan. 1969 and Novoja Vromja 17 Jan. 1969 as cited in UD, Sverige i Utlänsk press 1969, p.22. According to Swedish diplomatic reports, the Communist-world's enthusiasm for the Swedish decision was confirmed via both press reports and numerous diplomatic sources. 11 Jan. 1969. Gunnar Jarring. Telegram to UD. UD. Avd. HP Grupp 1. Mål Er. Politik Allmänt. Sovjet unionen. \# 312; 18 Jan. 1969. Hubert de Besche. Confidential telegram to UD. Re: Recent undated conversation with an unidentified Soviet diplomat in Washington UD. Avd. HP Grupp 1. Mål Ua. Politik Allmänt. Förenta Staterna. \# 227.

cxxxiv Jeremi Suri, Power and Protest: Global Revolution and the Rise of Detente (Cambridge, MA: Harvard University Press, 2003), pp.253-258. Here it is of great interest that Henry Kissinger draws attention to the fact that Sweden's criticism of the 1972 U.S. Christmas bombings was far more strident than either the official Soviet or Chinese response. Henry Kissinger, The White House Years (Boston: Little Brown, 1979), pp.1453-1454.

${ }_{\text {cxxxv }}$ Christer Jönsson and Bo Petersson undercut their own argument by conceding that the Soviets' limited propagandistic use of Swedish Vietnam criticism was possibly due to their own desire to avoid conflict with the U.S. Jönsson and Petersson, 'The Bear and the Mouse that Roared: Soviet Reactions to Public Swedish Criticism - Czechoslovakia and Vietnam,' p.87. Swedish diplomats in Moscow apparently drew the same conclusion. The Swedish Ambassador to the USSR, Gunnar Jarring, remarked that the Soviet press had not paid much attention to the Bertrand Russell War Crimes Tribunal in Sweden, presumably because the Kremlin was reluctant to antagonize the U.S. 8 May 1967. Gunnar Jarring. Confidential telegram to UD. UD. Avd. HP Grupp 1. Mål Er. Politik Allmänt. Sovjet unionen. \# 298.

cxxxvi 16 Aug. 1966. Political Section UD. Olle Tunborg. Memo. Re: Today's meeting between Torsten Nilsson and Nikolai Belochvostikov, the Soviet Ambassador to Sweden. UD. Avd. HP Grupp 1. Mål Er. Politik Allmänt. Sovjet unionen. \# 292; 17 May 1968. Jean-Christophe Öberg. Memo. Re: Today's meeting between and Torsten Nilsson and Viktor Maltev, the Soviet Ambassador to Sweden. UD. Avd. HP Grupp 1. Mål Er. Politik Allmänt. Sovjet unionen. \# 305; 26 Feb. 1971. Political Section UD. Rune Nyström. Memo. Re: Today's meeting between and Torsten Nilsson and Viktor Maltev. UD. Avd. HP Grupp 1. Mål Er. Politik Allmänt. Sovjet unionen. \# 339.

cxxxvii Petersson, Med Moskvas ögon, p.146; and Agrell, Fred och fruktan, pp.148-149.

cxxxviii For a specific illustration, see Christopher Jolin, Vänstervridningen (Malmö: Vox Förlag, 1972), pp.28-32, 137-139.

cxxxix Articles in Dagens Nyheter 10 March 1968, Katrineholms Kuriren 13 March 1968, Borås Tidning 31 March 1968, Vimmerby Tidning 11 Jan. 1969, Svenska Dagbladet 12 Jan. 1969, and Nya Wermlands Tidningen 13 Jan. 1969.

${ }^{c x 1} 6$ August 1965. J. Graham Parsons. Confidential telegram to State. Folder: Political \& Defense. Sweden, Box \# 2677, RG 59; 5 March 1966. J. Graham Parsons. Confidential telegram to State. Re: Kosygin's planned visit to Sweden in July 1966. Folder: Political \& Defense. Sweden, Box \# 2678, RG 59; 11 Aug. 1966. Wilhelm Wachtmeister. Memo. Re: Today's meeting between Torsten Nilsson and J. Graham Parsons. UD. Avd. HP Grupp 1. Mål Ua. Politik Allmänt. Förenta Staterna. \# 216; 14 Jan. 1969. Scandinavian Desk Dept. of State. George Ingram. Memo. Re: Today's meeting with Jean-Christophe Öberg at the U.S. Embassy in Stockholm. Folder: Political \& Defense. Sweden, Box \# 2505, RG 59; 13 
Dec. 1969. Turner Cameron, Jr. Telegram to State. Folder: Political \& Defense. Sweden, Box \# 2505, RG 59.

cxli Carl-Gustaf Scott, 'Swedish Sanctuary of American Deserters during the Vietnam War: A facet of Social Democratic Domestic Politics,' Scandinavian Journal of History 2001 26(2), pp.123-142.

cxlii Fred och säkerhet. Svensk säkerhetspolitik 1969-1989, pp.155-159, 166-167; Petersson, Sovjetunionen och neutraliteten i Europa, p.51; and Kan, Sverige och Ryssland, p.143.

cxliii 25 Aug. 1965. Olle Tunborg. Memo. Re: Today's meeting between Torsten Nilsson and Nikolai Belochvostikov, the Soviet Ambassador to Sweden. UD. Avd. HP Grupp 1. Mål Er. Politik Allmänt. Sovjet unionen. \# 284; 22 July 1966. Wilhelm Wachtmeister. Memo. Re: Today's meeting between Torsten Nilsson and Nikolai Belochvostikov. UD. Avd. HP Grupp 1. Mål Er. Politik Allmänt. Sovjet unionen. \# 292; 30 May 1967. Gunnar Jarring. Confidential telegram to UD. UD. Avd. HP Grupp 1. Mål Er. Politik Allmänt. Sovjet unionen. \# 298; 18 March 1968. Political Section UD. Unsigned. Confidential telegram to the Swedish Embassy Moscow. Re: Today's meeting with Viktor Maltev, the Soviet Ambassador to Sweden. UD. Avd. HP Grupp 1. Mål Er. Politik Allmänt. Sovjet unionen. \# 304; 16 June 1972. Political Section UD. Göran Berg. Memo. Re: Today's meeting with the Second Secretary of the Soviet Embassy, Mr. Svetanko. UD. Avd. HP Grupp 1. Mål Er. Politik Allmänt. Sovjet unionen. \# 342; 30 Jan. 1973. Gunnar Jarring. Confidential telegram to UD. Re: Yesterday's meeting between the Soviet Vice Prime Minister, Mr. Mazurov and Social Democratic cabinet member, Sven Aspling in Moscow. UD. Avd. HP Grupp 1. Mål Er. Politik Allmänt. Sovjet unionen. \# 347; 27 Feb. 1973. Rune Nyström. Memo. Re: Today's meeting between Foreign Minister Krister Wickman and Mikhail Jakovlev, the Soviet Ambassador to Sweden. UD. Avd. HP Grupp 1. Mål Er. Politik Allmänt. Sovjet unionen. \# 348.

cxliv Torsten Nilsson's address to Stockholm's SAP District on 23 April 1966 (Stockholms

Arbetarekommun, Arsmöte protokoll, 23 April 1966, pp.7-8.); Nilsson's comments to Stockholm's SAP District on 15 April 1967 (Stockholms Arbetarekommun, Årsmöte protokoll, 15 April 1967, p.14.) See also Kaj Björk's op-ed in Arbetet 20 May 1967.

cxlv Björk, Vägen till Indokina, pp.141, 228. This fact was also confirmed by the former SAP Party Secretary, Sten Andersson. Andersson interview with author, 27 May 2004.

cxlvi Articles in Dagens Nyheter 7 June 1966, Ny Dag 18 July 1968, and Svenska Dagbladet 19 June 1970. That the two countries shared a similar standpoint on the Vietnam issue was frequently reiterated during private meetings between Swedish and Soviet officials. 25 Aug. 1965. Olle Tunborg. Memo. Re: Today's meeting between Torsten Nilsson and Nikolai Belochvostikov, the Soviet Ambassador to Sweden. UD. Avd. HP Grupp 1. Mål Er. Politik Allmänt. Sovjet unionen. \# 284; 27 Dec. 1967. Leif Leifland. Memo. Re: Today's meeting between Torsten Nilsson and Andrei Gromyko in Moscow. UD. Avd. HP Grupp 1. Mål Er. Politik Allmänt. Sovjet unionen. \# 303; 18 March 1968. Political Section UD. Unsigned. Confidential telegram to the Swedish Embassy Moscow. Re: Today's meeting with Viktor Maltev, the Soviet Ambassador to Sweden. UD. Avd. HP Grupp 1. Mål Er. Politik Allmänt. Sovjet unionen. \# 304; 27 Feb. 1973. Rune Nyström. Memo. Re: Today's meeting between Foreign Minister Krister Wickman and Mikhail Jakovlev, the Soviet Ambassador to Sweden. UD. Avd. HP Grupp 1. Mål Er. Politik Allmänt. Sovjet unionen. \# 348.

cxlvii For specific illustrations, see joint communiqués issued in conjunction with official visits between Sweden and the USSR 17 June 1965, Yugoslavia 29 Oct. 1965 (as cited in UD, Utrikesfragor 1965, pp.149-153); Czechoslovakia 1 April 1966, Poland 9 June 1966 (as cited in UD, Utrikesfrågor 1966, pp.146-149); Hungary 11 April 1967, Romania 7 May 1967, Bulgaria 13 May 1967, USSR 1 Dec. 1967 (as cited in UD, Utrikesfrågor 1967, pp.177-183); USSR 13 July 1968 (as cited in UD, Utrikesfrågor 1968, pp.259-263); USSR June 191970 (as cited in UD, Utrikesfrågor 1970, pp.227-231); USSR 11 Feb 1972, Poland 8 March 1972 (as cited in UD, Utrikesfrågor 1972, pp.290-292); and USSR 6 April 1973, Poland 4 May 1973 (as cited in UD, Utrikesfrågor 1973, pp.241-245). However, if one, for example, in contrast examines the joint communiqués issued in conjunction with the Italian and West German official state visits to Sweden in 1966, neither one mentions Indochina. UD, Utrikesfrågor 1966, pp.149-151. According to Kaj Björk, the Swedish government had initially sought to avoid making any joint statements with the Soviets about the Vietnamese conflict. Björk, Vägen till Indokina, p.103. This resolve appears to have disappeared rather quickly.

cxlviii See, for example, Tage Erlander's remarks as cited in Dagens Nyheter 12 July 1968. This issue was also discussed among the Social Democratic parliamentary group on 10 April 1973 (SAP

Riksdagsgruppensprotokoll 10 April 1973.) 
cxlix 12 May 1967. U.S. Ambassador to Rumania. Richard Davis. Telegram to State. Re: Visit of Swedish Foreign Minister to Rumania 3-7 May 1967. Folder: Political \& Defense. Sweden, Box \# 2506, RG 59; 27 Oct. 1967. Jerome Holloway. Confidential telegram to State. Folder: Political \& Defense. Sweden, Box \# 2504, RG 59; 19 July 1968. Cameron Turner Jr. Telegram to State. Folder: Political \& Defense. Sweden, Box \# 2505, RG 59; 1 July 1970. Scandinavian Desk Dept. of State. George Mason Ingram. Briefing Memo to Martin Hillenbrand. Re: Upcoming meeting with the Swedish Ambassador to the U.S. on 2 July. Folder: Political \& Defense. Sweden, Box \# 2610, RG 59.

${ }^{c l}$ Kurt Törnqvist, Svenskarna och omvärlden (Stockholm: Beredskapsnämnden för psykologiskt försvar, 1969), pp.7-8, 10, 35-36; and Olof Petersson, Väljarna och världspolitiken (Stockholm: PA Nordstedt \& Söners Förlag, 1982), pp.11, 21, 43, 53.

cli Kjell Östberg, 'Inte som i Ryssland. 60-talet, vänstern och Sovjetunionen,' in Håkan Blomqvist and Lars Ekdahl (eds.), Kommunismen. Hot och löfte (Stockholm: Carlssons, 2002), pp.230-253.

clii 8 July 1966. J. Graham Parsons. Memo. "U.S. Policy Assessment - Sweden 1966." Folder: Political \& Defense. Sweden, Box \# 2678, RG 59; 11 June 1968. William W. Heath. Memo. "U.S. Policy Assessment Sweden 1968.” Folder: Political \& Defense. Sweden, Box \# 2504, RG 59; Undated (ca April 1970). European Section Dept. of State. Unsigned. Secret Memo. "Briefing Material for Ambassador Holland's Arrival in Stockholm - April 1970." Folder: Political \& Defense. Sweden, Box \# 2610, RG 59; 23 Aug. 1972. Jerome Holland. Confidential telegram to State. "U.S. Policy Assessment - Sweden 1972." Folder: Political \& Defense. Sweden, Box \# 2611, RG 59. This was also later confirmed by John Owens. Interview with John Owens, Scandinavian Desk 1973-1974. Dept. of State. Oral History Project. Georgetown University, 62.

cliii Om Kriget kommit. Förbredelser för motagande av militärt bistånd 1949-1969 (SOU 1994: 11), pp.301308; and Fred och säkerhet. Svensk säkerhetspolitik 1969-1989, pp.268, 283-288, 692. See also Ingemar Dörfer, Arms Deal: The Selling of the F-16 (New York: Prager, 1983), p.183; and Leifland, Frostens Ar, p. 180 .

cliv 3 March 1965. J. Graham Parsons. Confidential telegram to State. Folder: Political \& Defense. Sweden, Box \# 2677, RG 59; Undated (ca Jan-March 1967). Scandinavian Desk Dept. of State. Paul Hughes. Memo. Folder: Political \& Defense. Sweden, Box \# 2504, RG 59; 3 June 1969. David McKillop. Memo. Re: Munitions Control Policy Book. Folder: Defense. Sweden, Box \# 1613, RG 59; 4 Jan. 1971. Acting Secretary of State. Alexis U. Johnson. Telegram to the U.S. Embassy Stockholm. Folder: Political \& Defense. Sweden, Box \# 2610, RG 59; 23 Aug. 1972. Jerome Holland. Confidential telegram to State. Re: "U.S. Policy Assessment - Sweden 1972.” Folder: Political \& Defense. Sweden, Box \# 2611, RG 59. clv 8 July 1966. J. Graham Parsons. Confidential telegram to State. Re: "U.S. Policy Assessment - Sweden 1966." Folder: Political \& Defense. Sweden, Box \# 2678, RG 59; 20 Jan. 1967. J. Graham Parsons. Confidential telegram to State. Folder: Political \& Defense. Sweden, Box \# 2504, RG 59; Undated (ca April 1970). European Section Dept. of State. Unsigned. Secret Memo. Re: "Briefing Material for Ambassador Holland's Arrival in Sweden - April 1970." Folder: Political \& Defense. Sweden, Box \# 2610, RG 59; 31 July 1972. Executive Secretary Dept. of State. Memo to Brig. General John M. Dunn, Office of the Vice-President. Folder: Sweden, NSC Files, Box \# 707, Nixon Project.

${ }^{c l v i}$ Fred och säkerhet. Svensk säkerhetspolitik 1969-1989, pp.240-242, 246-291; and Leifland, Frostens år, pp.105-107. 